\title{
ARTICLE
}

\section{Molecular Complexes and Main-Chain Organometallic Polymers Based on Janus Bis(carbenes) Fused to Metalloporphyrins}

Received 00th January 20xx, Accepted 00th January 20xx DOI: $10.1039 / x 0 x x 00000 x$

\author{
Jean-François Longevial, ${ }^{\text {ab }}$ Mamadou Lo, ${ }^{\text {ac }}$ Aurélien Lebrun, ${ }^{d}$ Danielle Laurencin, ${ }^{\text {a }}$ Sébastien \\ Clément, ${ }^{\mathrm{a}}$ and Sébastien Richeter*a
}

\section{Introduction}

In the field of organometallic chemistry, $\mathrm{N}$-heterocyclic carbenes (NHCs) occupy a privileged place among all other ligands: (i) they can bind most of the transition metal ions in low and high oxidation states; (ii) their binding strength to metals is stronger than that of phosphines and (iii) their steric and electronic properties can be easily tuned (especially for NHCs belonging to the imidazol-2-ylidenes family). ${ }^{1-7}$ For all these reasons, NHCs are being actively investigated as ancillary ligands in homogeneous catalysis, in which a precise control over the steric and electronic properties is needed. ${ }^{8}$ Nowadays, the success story of NHC-metal complexes in catalysis is still ongoing. Moreover, their application in different research fields such as the development of new metallodrugs ${ }^{5}$ or functional materials ${ }^{9}$ is also underway. In this context, poly(NHCs) ligands containing two or more NHCs have progressively been developed to expand the scope of possible applications. The coordination modes of these poly(NHCs) i.e. chelating mode or bridging mode strongly depends on their backbone structure. The chelating mode is when two NHCs bind one metal centre. ${ }^{10-}$ 13 The bridging mode instead is when the two NHCs bind two different metal centres. ${ }^{14-18}$ Many examples of bis(NHCs) acting as chelating ligands can be found in the literature since they

a.ICGM, Univ Montpellier, CNRS, ENSCM, CC 1701, Campus Triolet, Place Eugène Bataillon, Montpellier, France.

b. CINAM, Univ Aix-Marseille, CNRS, Centre Interdisciplinaire de Nanoscience de Marseille, Campus de Luminy, Marseille, France.

. UFR des Sciences et Technologies, Univ Assane Seck de Ziguinchor, DiabirZiguinchor, Sénégal.

d. Laboratoire de Mesures Physiques, Univ Montpellier, Campus Triolet, Place Eugène Bataillon, Montpellier, France.

E-mail: jean-francois.longevial@umontpellier.fr sebastien.richeter@umontpellier.fr

Electronic Supplementary Information (ESI) available: [details of any supplementary information available should be included here]. See DOI: 10.1039/x0xx00000x

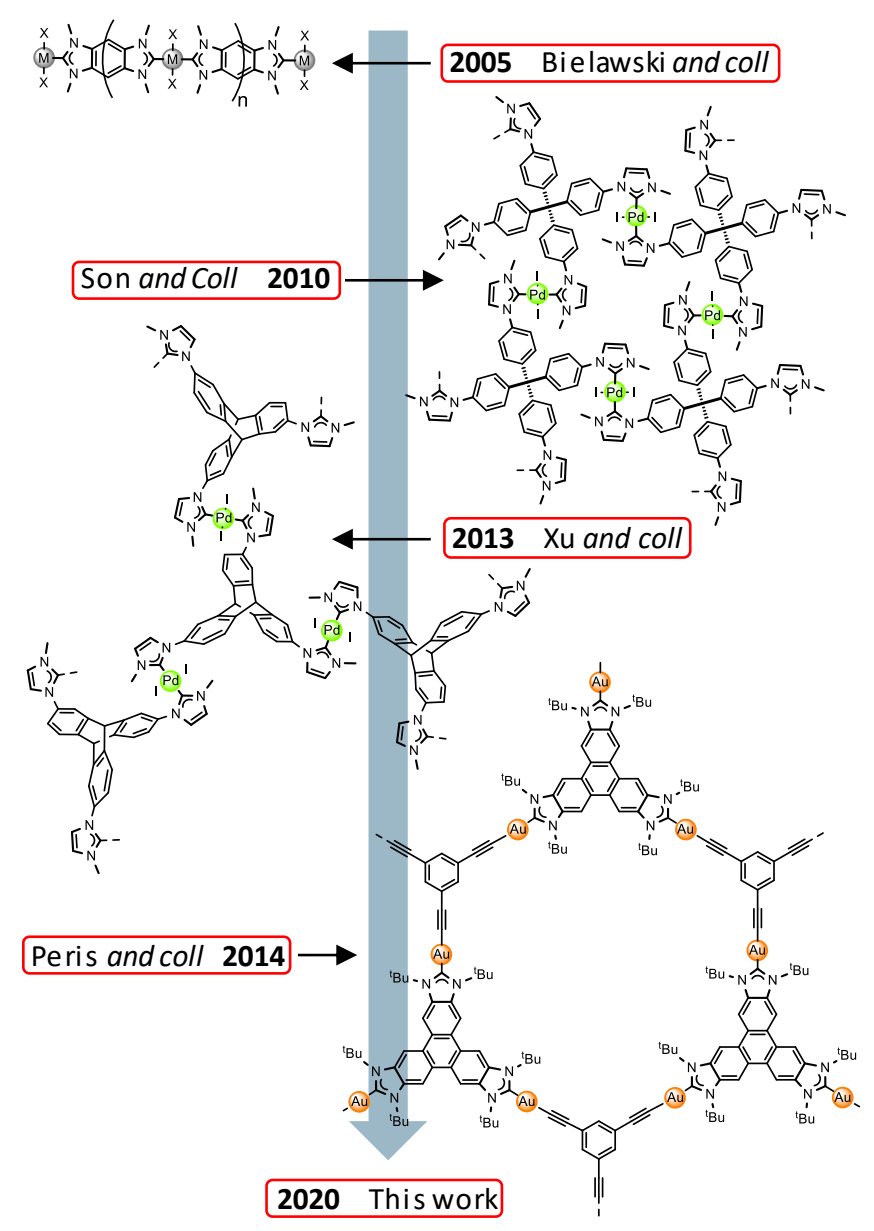

Figure 1. Examples of NHC-based organometallic polymers reported in the literature.

have found useful applications in catalysis. ${ }^{11,19-21}$ On the contrary, examples of non-chelating bis(NHC)s acting as bridging ligands are relatively scarce. For this purpose, rigid 
spacers such as $\pi$-conjugated systems are often used to obtain bis(NHC)s featuring linearly opposed coordination sites. ${ }^{14,22-26}$

Poly(NHCs) fused to polyaromatic systems are also interesting ligands because supramolecular interactions such as $\pi$-stacking interactions can be used to obtain innovative selfassembled metallosupramolecular architectures, ${ }^{24-26}$ or to modulate the catalytic activities of molecular organometallic complexes. ${ }^{27}$ These ligands also allow the preparation of luminescent complexes ${ }^{28}$ and conducting and/or emissive materials. ${ }^{29}$ They are also of great interest for the preparation of molecular materials such as main-chain organometallic polymers (MCOPs) (Figure 1). ${ }^{30-33}$ Such materials could be obtained with triptycene-based tris(NHCs) ${ }^{32}$ and tetraphenylmethane tetrakis(NHCs) ${ }^{31}$ ligands through the formation of $\mathrm{C}_{\mathrm{NHC}}-\mathrm{Pd}-\mathrm{C}_{\mathrm{NHC}}$ bonds, for example. Peris and coworkers prepared MCOPs with triphenylene-based tris(NHCs) ligands through the formation of $\mathrm{C}_{\mathrm{NHC}}-\mathrm{Au}-\mathrm{C}_{\text {acetylide }}$ bonds. ${ }^{33}$ These MCOPs were then used as insoluble materials for heterogenous catalysis.

We have previously shown that porphyrins fused to imidazolium rings could be used as NHC precurors to anchor different metal ions such as palladium, ${ }^{34,35}$ rhodium, ${ }^{36}$ silver $^{37}$ and gold 38,39 at their periphery. Recently, we reported the synthesis of porphyrins containing two imidazolium rings fused to two opposite pyrrole units. ${ }^{40}$ Here, we show that this Janus bis(NHCs) precursors can be used for the preparation of molecular trinuclear metal complexes (one metal ion in the porphyrin core and two others at the periphery, as illustrated in Figure 2, left side). Furthermore, we synthesized MCOPs containing polyacetylides and used them for photocatalytic applications.

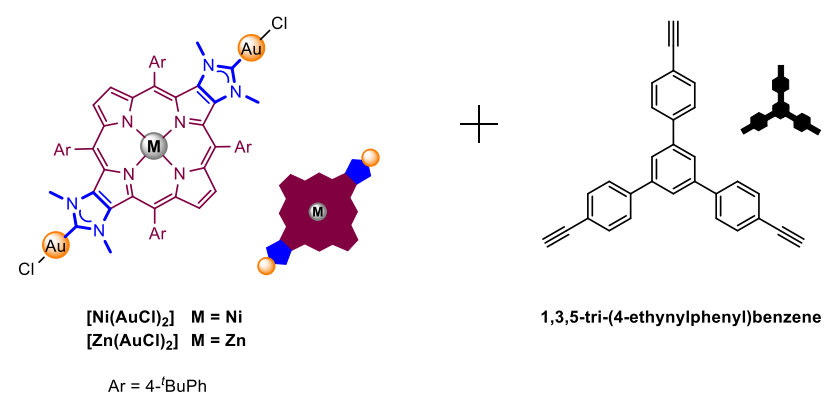

Figure 2. Building blocks used in this study for the synthesis of MCOPs.

\section{Results and discussion}

\section{Synthesis and characterization of Janus bis(NHC) gold(I) chloride} complexes.

The nickel(II) porphyrin $\mathbf{N i - I m i}$ containing two imidazole rings fused to two opposite pyrrole units was synthesized in eight steps and $14 \%$ global yield, starting from nickel(II) meso tetra(4tert-butylphenyl)porphyrin and following our reported procedure. ${ }^{41}$ Methylation of the four imidazole nitrogen atoms with an excess of iodomethane in the presence of $\mathrm{K}_{2} \mathrm{CO}_{3}$ in DMF

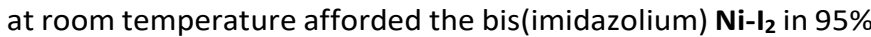
yield (Scheme 1). The bis(imidazolium) $\mathbf{Z n}-\mathbf{I}_{\mathbf{2}}$ was obtained in

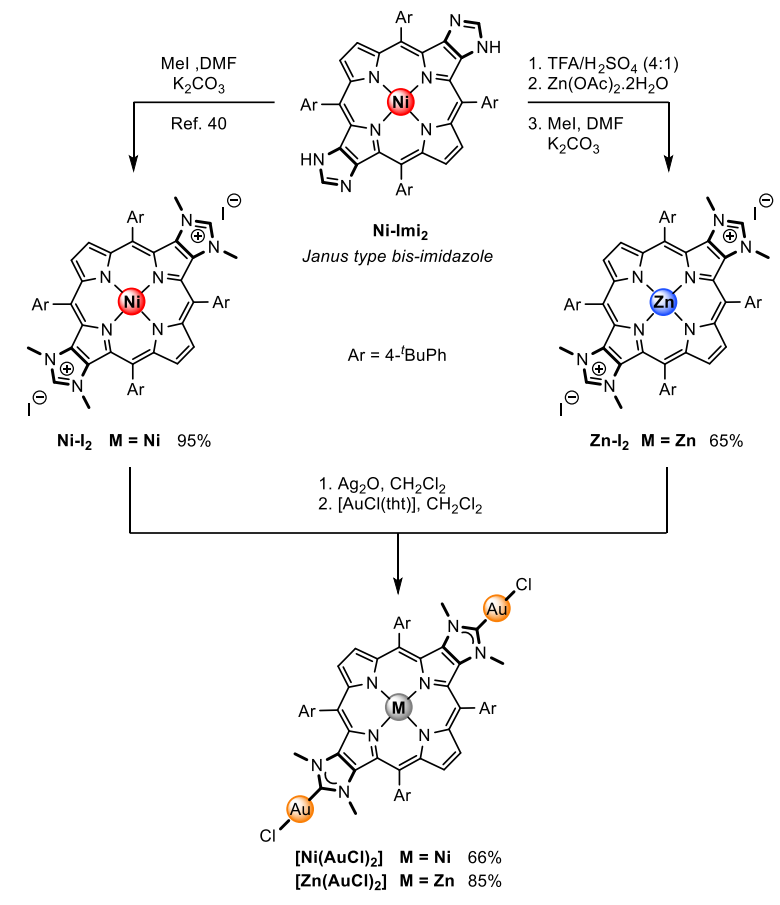

Scheme 1. Synthetic approach for preparing porphyrins fused to Janus bis-( $N$ heterocyclic carbene)-gold complexes [Ni(AuCl $)_{2}$ ] and [ $\left.\mathrm{Zn}(\mathrm{AuCl})_{2}\right]$.

two steps. First, the bis(imidazole) $\mathbf{N i}-\mathbf{I m i}_{2}$ was demetalated with a TFA $/ \mathrm{H}_{2} \mathrm{SO}_{4}$ 4:1 mixture. The obtained free base bis(imidazole) derivative, which appeared to be air- and lightsensitive, was not isolated and was immediately metalated with $\mathrm{Zn}(\mathrm{OAc})_{2} \cdot 2 \mathrm{H}_{2} \mathrm{O}$ in a $\mathrm{CHCl}_{3} / \mathrm{MeOH} 6: 1$ mixture at $45^{\circ} \mathrm{C}$ for $1 \mathrm{~h} .{ }^{42}$ Complexation of zinc(II) was confirmed by UV-Vis absorption spectroscopy showing the two characteristic $Q$ bands of zinc(II)porphyrin at 535 and $689 \mathrm{~nm}$. Afterwards, the two peripheral imidazole rings of $\mathbf{Z n}-\mathbf{I} \mathbf{m i}_{\mathbf{2}}$ were methylated as described above to obtain the corresponding bis(imidazolium) $\mathbf{Z n}-\mathbf{I}_{\mathbf{2}}$ in a global

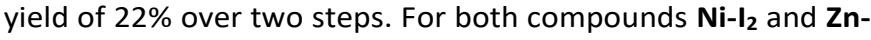
$\mathbf{I}_{2}$, the methylation reaction was confirmed by ${ }^{1} \mathrm{H} N M R$ spectroscopy. Indeed, a singlet corresponding to the four $\mathrm{N}-\mathrm{CH}_{3}$

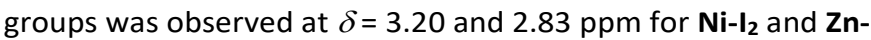
$\mathbf{I}_{2}$, respectively. Moreover, a sharp singlet corresponding to the two imidazolium protons was observed $\delta=10.79$ and 10.05 ppm for $\mathbf{N i}-\mathbf{I}_{\mathbf{2}}$ and $\mathbf{Z n}-\mathbf{I}_{\mathbf{2}}$, respectively. The $\mathbf{N i}-\mathbf{I}_{\mathbf{2}}$ and $\mathbf{Z n}-\mathbf{I}_{\mathbf{2}}$ dications were observed by $\operatorname{ESI-TOF}(+)$ mass spectrometry at $m / z=516.3\left(\mathrm{~m} / z\right.$ calc. for $\left.\mathrm{C}_{66} \mathrm{H}_{70} \mathrm{~N}_{8} \mathrm{Ni} 516.3 \mathrm{Da}[\mathrm{M}-2 \mathrm{l}]^{2+}\right)$ and $\mathrm{m} / z$ $=519.3\left(\mathrm{~m} / z\right.$ calc. for $\mathrm{C}_{66} \mathrm{H}_{70} \mathrm{~N}_{8} \mathrm{Zn} 519.3$ Da $\left.[\mathrm{M}-2 \mathrm{I}]^{2+}\right)$, respectively.

We have previously shown that porphyrins fused to one imidazolium ring across two neighboring $\beta, \beta$-pyrrolic positions can be used as NHC precursors to synthesize mono(NHC) gold(I) complexes such as [NiAuCl]. ${ }^{38}$ A commonly used synthetic strategy consists in forming the NHC-silver(I) complex followed by a transmetalation with $[\mathrm{AuCl}(\mathrm{tht})]$ (tht = tetrahydrothiophene). Janus bis(NHCs) gold(I) complexes $\left[\mathrm{Ni}(\mathrm{AuCl})_{2}\right]$ and $\left[\mathrm{Zn}(\mathrm{AuCl})_{2}\right]$ were obtained in $65 \%$ and $85 \%$ yield, respectively, following a similar procedure. It is worth noting that these complexes are very stable and could be purified by silica gel column chromatography. The characteristic ${ }^{13} \mathrm{C} N \mathrm{NMR}$ signal of the NHCs was observed at $\delta=182.7$ and $182.0 \mathrm{ppm}$ on 
the ${ }^{13} \mathrm{C}\left\{{ }^{1} \mathrm{H}\right\}$ NMR spectra of $\left[\mathrm{Ni}(\mathrm{AuCl})_{2}\right]$ and $\left[\mathrm{Zn}(\mathrm{AuCl})_{2}\right]$, respectively, confirming the formation of the $\mathrm{C}_{\mathrm{NHC}}-\mathrm{AuC}$ bonds. ${ }^{1,43}$ The parent mass peaks could also be observed in their MALDI-TOF $(+)$ mass spectra at $m / z=1494.4$ Da $(\mathrm{m} / z$ calc. for $\mathrm{C}_{66} \mathrm{H}_{68} \mathrm{Au}_{2} \mathrm{Cl}_{2} \mathrm{~N}_{8} \mathrm{Ni}$ 1494.4 Da [M] $\left.{ }^{\bullet+}\right)$ for [Ni(AuCl$)_{2}$ ] and at $\mathrm{m} / \mathrm{z}=$ 1500.3 Da (m/z calc. for $\left.\mathrm{C}_{66} \mathrm{H}_{68} \mathrm{Au}_{2} \mathrm{Cl}_{2} \mathrm{~N}_{8} \mathrm{Zn}: 1500.4 \mathrm{Da}[\mathrm{M}]^{\circ+}\right)$ for [Zn(AuCl) 2 .

\section{Synthesis and characterization of mono- and bis-(NHC)-gold(I)- acetylide complexes.}

Ott ${ }^{44}$ and Peris's ${ }^{33}$ groups showed that the reaction between gold (I) complexes [(NHC)-Au-Cl] and acetylides (generated in situ through deprotonation of the corresponding terminal acetylenes with a base) afforded the desired complexes [(NHC)$\mathrm{Au}-\mathrm{C} \equiv \mathrm{C}-\mathrm{R}]$. Following a similar strategy, we synthesized the corresponding mono(NHC) gold(I) acetylide complex [NiAuPh] in $66 \%$ yield by reacting [NiAuCl] with phenylacetylene using slightly modified conditions (i.e. $\mathrm{KOH}, \mathrm{MeOH} / \mathrm{THF}$ ) (Scheme 2 anf Figure 3). ${ }^{44,45}$

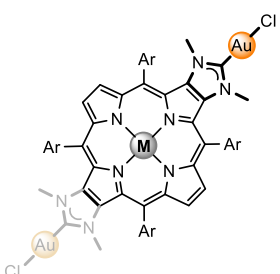

[M(AuCl) $n]$

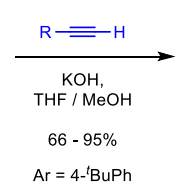

$\mathrm{Ar}=4-{ }^{\mathrm{t}} \mathrm{BuPh}$

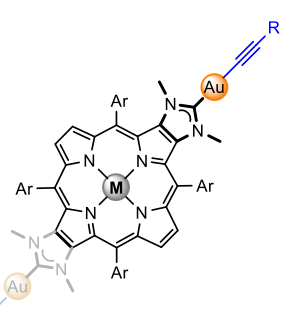

[M(AuR) $]$
Scheme 2. General scheme for the synthesis of porphyrins fused to NHC gold(I) alkynyl complexes. $M=N i$ or $\mathrm{Zn}, \mathrm{n}=1$ with porphyrin mono(NHC), $n=2$ with
porphyrin bis(NHC), $\mathrm{R}$ is an aromatic or a polyaromatic scaffold (see Figure 3 ).

It should be noted that [NiAuPh] could only be purified by recrystallization from $\mathrm{CH}_{2} \mathrm{Cl}_{2} / \mathrm{MeOH}$, because it decomposed on both silica gel and alumina columns. All spectroscopic data were in good agreement with the structure proposed for [NiAuPh]. Its parent mass peak was clearly observed at $m / z=1620.4597$ ( $\mathrm{m} / \mathrm{z}$ calc. for $\mathrm{C}_{71} \mathrm{H}_{69} \mathrm{AuN}_{6} \mathrm{Ni} 1260.4603 \mathrm{Da}[\mathrm{M}]^{\bullet+}$ ) by ESI-TOF $(+)$ high-resolution mass spectrometry. The presence of the gold(I) phenylacetylide moiety was also confirmed by ${ }^{1} \mathrm{H}$ and ${ }^{13} \mathrm{C}\left\{{ }^{1} \mathrm{H}\right\}$ NMR spectroscopy. The principal information arises from the presence of a multiplet between $\delta=7.13-7.35 \mathrm{ppm}$ corresponding to the $5 \mathrm{H}$ of the phenyl group. Moreover, six new signals appeared in its ${ }^{13} \mathrm{C}\left\{{ }^{1} \mathrm{H}\right\}$ NMR spectrum. Two of them at $\delta$ $=128.5$ and $105.0 \mathrm{ppm}$ can be attributed to the two hybridized $s p$ carbon atoms $\mathrm{Au}-\boldsymbol{C} \equiv \mathrm{C}$ and $\mathrm{Au}-\mathrm{C} \equiv \boldsymbol{C}$, respectively. ${ }^{44,46,47}$ The $s p$ carbon atom directly linked to the gold $(\mathrm{I})$ atom appeared more downfield shifted which is in accordance with the chemical shifts reported in the literature. ${ }^{44} \mathrm{~A}$ downfield shift of $\sim 16 \mathrm{ppm}$ was also observed for the resonance of the $\mathrm{C}_{\mathrm{NHC}}$ at $\delta=198.7$ ppm ( $\delta=182.3 \mathrm{ppm}$ for [NiAuCl]). Finally, IR spectroscopy revealed the presence of the $\mathrm{C} \equiv \mathrm{C}$ stretching frequency at $v=$ $2114 \mathrm{~cm}^{-1}$.

In view of synthetizing MCOPs with the $\mathrm{C}_{\mathrm{NHC}}-\mathrm{Au}-\mathrm{C}_{\text {acetylide }}$ structural features, the reactivity of [NiAuCl] with polyacetylides derived from 1,4-diethynylbenzene ${ }^{48}$ and 1,3,5- tri(4-ethynylphenyl)benzene ${ }^{49}$ was investigated (Figure 3). Satisfyingly, tetranuclear $\mathbf{N i}_{2}$ and hexanuclear $\mathbf{N i}_{3}$ complexes were obtained in high yields of $75 \%$ and $95 \%$, respectively. For complex $\mathbf{N i}_{2}$, expected parent mass peaks was observed at $\mathrm{m} / \mathrm{z}$ $=2442.8\left(\mathrm{~m} / z\right.$ calc. for $\left.\mathrm{C}_{136} \mathrm{H}_{132} \mathrm{Au}_{2} \mathrm{~N}_{12} \mathrm{Ni}_{2} 2442.9 \mathrm{Da}[\mathrm{M}]^{\bullet+}\right)$ by MALDI-TOF(+) MS. The aromatic protons signal corresponding to the assembling phenyl group was observed as a singlet at $\delta=$ $7.21 \mathrm{ppm}$ by ${ }^{1} \mathrm{H}$ NMR spectroscopy. Similarly to [NiAuPh], the ${ }^{13} \mathrm{C}\left\{{ }^{1} \mathrm{H}\right\}$ NMR spectrum of complex $\mathbf{N i}_{2}$ features the $s p$ carbon atom signal at $\delta=125.5$ ( $\mathrm{Au}-\mathrm{C} \equiv \mathrm{C}$ ) and 104.8 (Au-C $\equiv C$ ) ppm, while the signal of the $\mathrm{C}_{\mathrm{NHC}}$ was observed at $\delta=198.6 \mathrm{ppm}$. For complex $\mathrm{Ni}_{3}$, the expected parent mass peaks was observed at $m / z=3854.4\left(\mathrm{~m} / z\right.$ calc. for $\left.\mathrm{C}_{219} \mathrm{H}_{208} \mathrm{Au}_{3} \mathrm{~N}_{18} \mathrm{Ni}_{3} 3854.4 \mathrm{Da}[\mathrm{M}+\mathrm{H}]^{+}\right)$ by MALDI-TOF(+) MS, and similar observations could be made when comparing ${ }^{1} \mathrm{H}$ and ${ }^{13} \mathrm{C}\left\{{ }^{1} \mathrm{H}\right\}$ NMR spectra of complexes $\mathbf{N i}_{3}$ and $\mathbf{N i}_{2} .{ }^{1} \mathrm{H}$ 2D DOSY NMR spectroscopy was also found to be a useful technique to characterize multiporphyrinic compounds with different sizes and shapes, leading thus to different diffusion coefficients. ${ }^{1} \mathrm{H}$ 2D DOSY NMR spectra of [NiAuPh] (blue), $\mathbf{N i}_{\mathbf{2}}$ (green), and $\mathbf{N i}_{\mathbf{3}}$ (pink) are superimposed in Figure 4. For each compound, the porphyrin and acetylide moieties were found to diffuse simultaneously as expected for fragments

Figure 3. Scope of the studied reaction and corresponding yields.

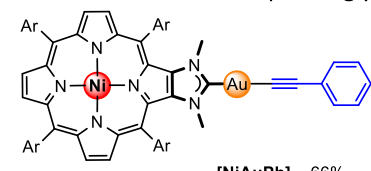

$$
\text { [NiAuPh] } 66 \%
$$
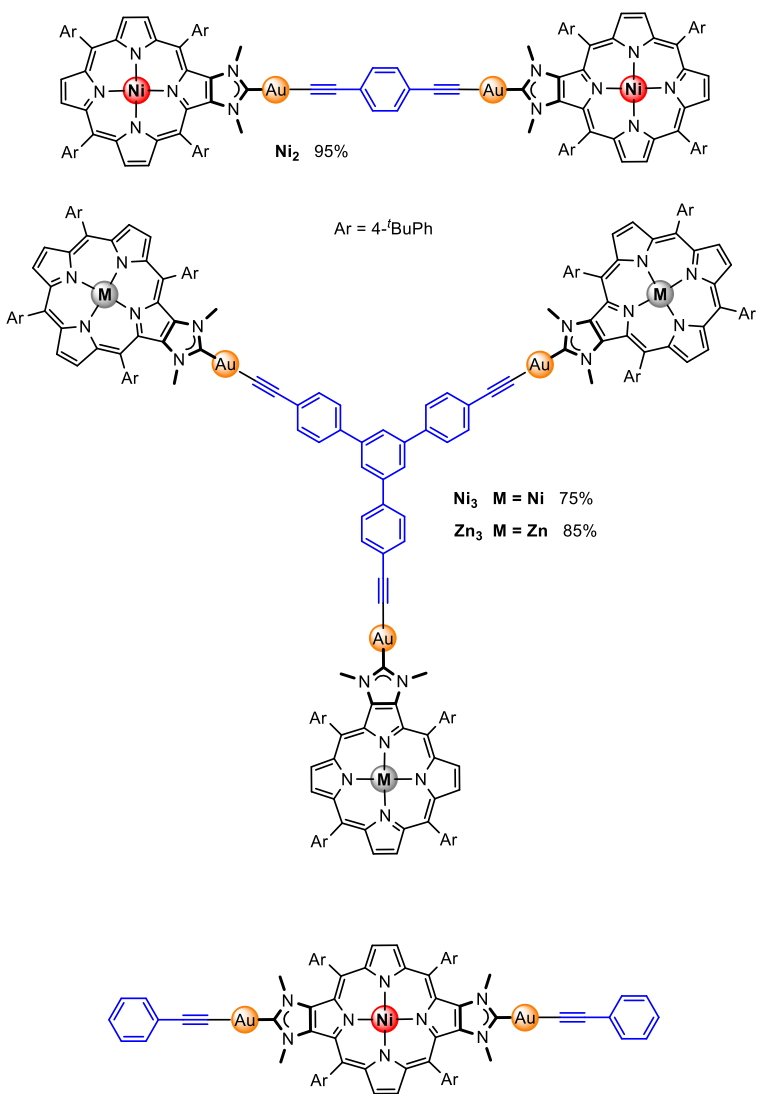

$\left[\mathrm{Ni}(\mathrm{AuPh})_{2}\right] \quad 80 \%$ 


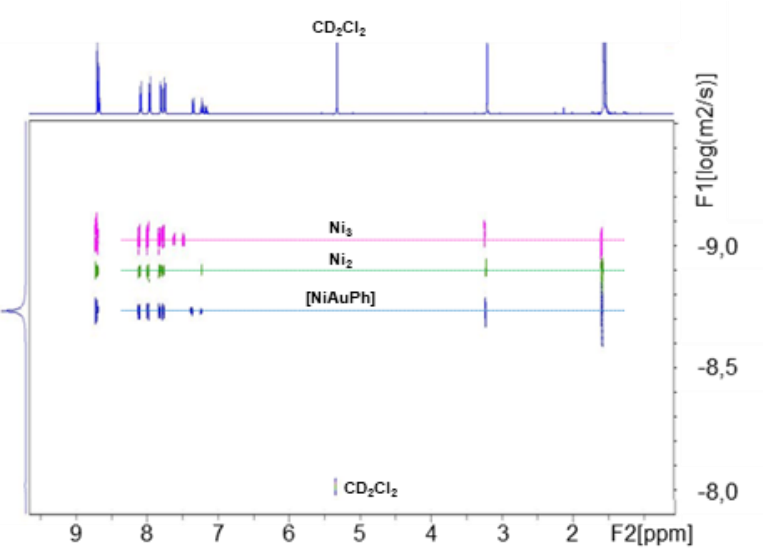

Figure 4. Superimposed ${ }^{1} \mathrm{H} 2 \mathrm{D}$ DOSY NMR spectra of [NiAuPh], $\mathbf{N i}_{2}, \mathbf{N i}_{3}$ measured in $\mathrm{CD}_{2} \mathrm{Cl}_{2}$ at $400 \mathrm{MHz}$ and $298 \mathrm{~K}$ Blue spectrum is the one of [NiAuPh].

belonging to the same molecular species. Moreover, the three complexes did not diffuse at the same rate. The smallest dinuclear complex [NiAuPh] has the highest diffusion coefficient ( $D=5.88 \times 10^{-10} \mathrm{~m}^{2} \mathrm{~s}^{-1}$ in $\mathrm{CD}_{2} \mathrm{Cl}_{2}$ at 298K). Tetranuclear and hexanuclear complexes $\mathbf{N i}_{\mathbf{2}}$ and $\mathbf{N i}_{3}$ have lower diffusion coefficients $\left(D=3.96 \times 10^{-10}\right.$ and $2.95 \times 10^{-10} \mathrm{~m}^{2} \mathrm{~s}^{-1}$ in $\mathrm{CD}_{2} \mathrm{Cl}_{2}$ at $298 \mathrm{~K}$, respectively for $\mathbf{N i}_{2}$ and $\mathbf{N i}_{3}$ ). The analogous complex $\mathbf{Z n}_{\mathbf{3}}$, with zinc(II) in place of nickel(II), was also synthesized and fully characterized (see Electronic Supplementary Information) in view of using it as a reference compound when characterizing MCOPs based on porphyrin fused to Janus bis-(NHC)-gold complexes. All spectroscopic data obtained for hexanuclear $\mathbf{Z n}_{\mathbf{3}}$ are in agreement with the proposed structure and its diffusion coefficient measured by ${ }^{1} \mathrm{H}$ 2D DOSY NMR spectroscopy is close to the one measured for $\mathbf{N i}_{3}$ ( $D=2.80 \times 10^{-10} \mathrm{~m}^{2} \mathrm{~s}^{-1}$ in $\mathrm{CD}_{2} \mathrm{Cl}_{2}$ at $298 \mathrm{~K}$ ).

Finally, the trinuclear complex [Ni(AuPh $)_{2}$ ] with two opposed phenyalcetylide ligands was obtained in $80 \%$ yield by reacting two equivalents of phenylacetylene with one equivalent of trinuclear complex $\left[\mathrm{Ni}(\mathrm{AuCl})_{2}\right]$ in basic conditions. The parent ion peak was found at $m / z=1626.5 \mathrm{Da}(\mathrm{m} / \mathrm{z}$ calc. for $\mathrm{C}_{82} \mathrm{H}_{80} \mathrm{Au}_{2} \mathrm{~N}_{8} \mathrm{Ni} 1628.5 \mathrm{Da}[\mathrm{M}]^{\bullet+}$ ) by MALDI-TOF(+) MS. The presence of the alkynyl moieties was confirmed by ${ }^{1} \mathrm{H}$ NMR spectroscopy with the signals of the $s p$ carbon atoms at $\delta=$ 125.9 and $104.9 \mathrm{ppm}$. The two equivalent $\mathrm{C}_{\mathrm{NHC}}$ were observed at $\delta=199.4 \mathrm{ppm}$ by ${ }^{13} \mathrm{C}\left\{{ }^{1} \mathrm{H}\right\}$ NMR spectroscopy.

\section{Synthesis, characterization and properties of main-chain organometallic polymers (MCOPs).}

The data obtained in course of this study suggest that Janus bis(NHCs)-gold(I) complexes [ $\left.\mathrm{Ni}(\mathrm{AuCl})_{2}\right]$ and $\left[\mathrm{Zn}(\mathrm{AuCl})_{2}\right]$ combined to polyacetylides are suitable building blocks for the synthesis of MCOPs incorporating $\mathrm{C}_{\mathrm{NHC}}-\mathrm{Au}-\mathrm{C}_{\text {acetylide }}$ bonds. Indeed, MCOPs $\mathbf{N i}_{\text {mat }}$ and $\mathbf{Z} \mathbf{n}_{\text {mat }}$ were synthesized by using the slightly modified conditions developed by Peris et al (Scheme 3). ${ }^{33}$ The reaction of 1 equivalent of trinuclear complex [M(AuCl) $)_{2}(\mathrm{M}=\mathrm{Ni}$ or $\mathrm{Zn})$ with 1.5 equivalent of a trisalkynyl scaffold, namely, 1,3,5-tri(4-ethynylphenyl)benzene ${ }^{6}$ in basic conditions $\left(\mathrm{NaOH}\right.$ in a THF/MeOH mixture at $50^{\circ} \mathrm{C}$ ) afforded insoluble materials in $74 \%$ and $83 \%$ yield for $\mathbf{N i}_{\text {mat }}$ and $\mathbf{Z n}_{\text {mat }}$,

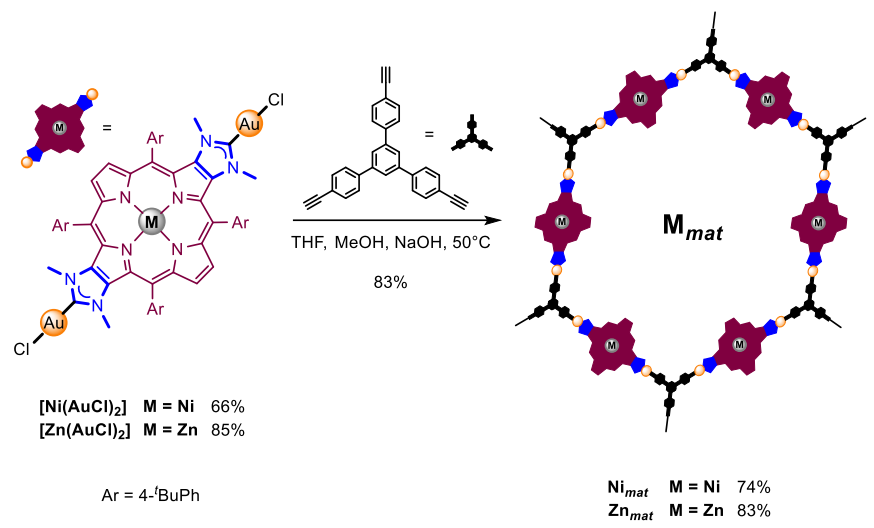

Scheme 3. Synthesis of Main-Chain Microporous Organometallic Polymers $\mathbf{N i}_{\text {mat }}$ and $\mathbf{Z n}_{\text {mat }}$

respectively. Both materials were fully characterized, as described below for $\mathbf{Z} \mathbf{n}_{\text {mat }}$ (data for $\mathbf{N i}_{\text {mat }}$ can be found in Electronic Supplementary Information). The solid material $\mathbf{Z n}_{\text {mat }}$ showed an amorphous character because no X-Ray diffraction peaks were observed on the X-Ray powder patterns recorded at wide and small angles. ${ }^{33}$ Thermal stability of $\mathbf{Z n}_{\text {mat }}$ was evaluated by thermogravimetric analysis (TGA), showing that $\mathbf{Z n}_{\text {mat }}$ is stable at least up to $300{ }^{\circ} \mathrm{C}$ with a degradation point starting at $320^{\circ} \mathrm{C}$ (Figure 5b). The high thermal stability is due to the porphyrins which are known to be thermally-stable at elevated temperatures. ${ }^{50}$ Chemical composition of $\mathbf{Z} \mathbf{n}_{\text {mat }}$ was determined by elemental analysis and the obtained data $\mathrm{C}$ $58.60, \mathrm{H} 4.89 \mathrm{~N} 6.20$ are globally in good agreement with the expected values calculated for the MCOP $\left(\mathrm{C}_{129} \mathrm{H}_{117} \mathrm{Au}_{3} \mathrm{~N}_{12} \mathrm{Zn}_{1.5}\right)_{\mathrm{n}}$

a)

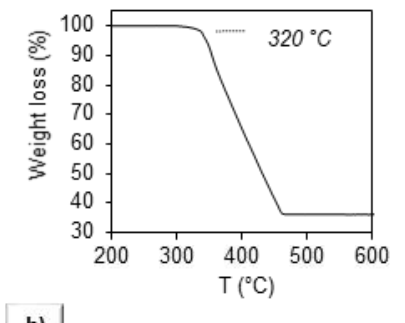

b)
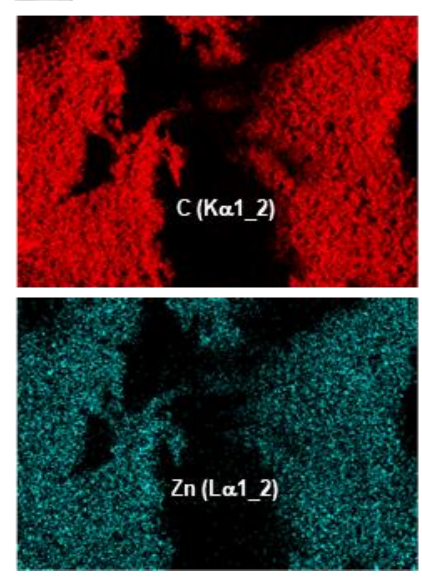

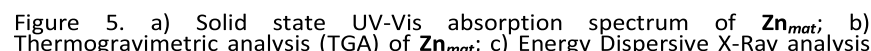
Thermogravimetric analysis (TGA) of $\mathbf{Z n}_{\text {mat }}$; c) Energy Dispersive X-Ray analys
(EDX) mapping of $\mathbf{Z n}_{\text {mat }}$ red: carbon; yellow: nitrogen; blue: zinc; purple: gold. c)
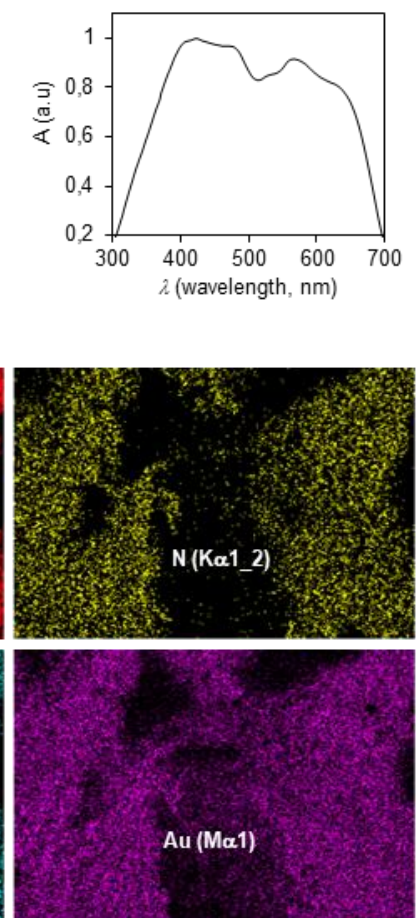
(C $61,42, \mathrm{H} \mathrm{4,68,} \mathrm{N} \mathrm{6,66).} \mathrm{To} \mathrm{support} \mathrm{these} \mathrm{data,} \mathrm{we} \mathrm{also}$ preformed elemental mapping by means of energy dispersive $X$ ray diffraction analysis (EDX). As can be seen in Figure $5 c$, the elemental mapping confirmed the homogenous distribution of $\mathrm{C}, \mathrm{N}, \mathrm{Zn}$ and $\mathrm{Au}$ elements among the sample. Moreover, EDX spectroscopy analysis also allows the determination of elementals ratios within the sample. We thus found an $\mathrm{Au} / \mathrm{Zn}$ ratio of $\sim 1: 2$, which is in good agreement with the proposed structure of $\mathbf{Z n}_{\text {mat }}$.

The structure of $\mathbf{Z} \mathbf{n}_{\text {mat }}$ at the molecular level was elucidated by combining infrared (IR) spectroscopy and ${ }^{13} \mathrm{C}$ solid state NMR spectroscopy. The IR spectrum of $\mathbf{Z} \mathbf{n}_{\text {mat }}$ displayed the $\mathrm{C} \equiv \mathrm{C}$ stretching frequency at $v=2104 \mathrm{~cm}^{-1}$ confirming the presence of $\mathrm{C} \equiv \mathrm{C}$ bonds. ${ }^{13} \mathrm{C}$ solid state NMR was used to confirm the formation of $\mathrm{C}_{\mathrm{NHC}}-\mathrm{Au}$ bonds (Figure 6). Here, the hexanuclear complex $\mathbf{Z n}_{3}$ (described above) was used as a reference compound because (i) it contains similar connections and ligands; (ii) it had been fully characterized in solution. On the ${ }^{13} \mathrm{C}$ solution NMR spectrum of $\mathbf{Z} \mathbf{n}_{3}$, the signal of the $\mathrm{C}_{\mathrm{NHC}}$ appears at $\delta=199.4 \mathrm{ppm}$. Similarly, the signal of the $\mathrm{C}_{\mathrm{NHC}}$ is clearly visible at $\delta \sim 200 \mathrm{ppm}$ on the ${ }^{13} \mathrm{C}$ CP MAS (Cross-Polarization magic Angle Spinning) NMR spectrum. Such a chemical shift $\delta \sim 200$ ppm is also observable on the ${ }^{13} \mathrm{C} C P$ MAS NMR spectrum of $\mathbf{Z n}_{\text {mat }}$, confirming the presence of $\mathrm{C}_{\mathrm{NHC}}-\mathrm{Au}-\mathrm{C} \equiv \mathrm{C}$ bonds. Moreover, the ${ }^{13} \mathrm{C}$ CP MAS NMR spectrum of $\mathbf{Z n}_{\text {mat }}$ also displays the characteristic signal of the $\mathrm{Au}-\mathrm{C} \equiv \boldsymbol{C}$ carbon at $\delta \sim 105 \mathrm{ppm} .{ }^{44-}$ ${ }^{46}$ The similarities between the ${ }^{13} \mathrm{C}$ CP MAS NMR spectra of $\mathbf{Z} \mathbf{n}_{\text {mat }}$ and the corresponding model compound $\mathbf{Z n}_{\mathbf{3}}$ strongly suggest the formation of an insoluble MCOP with porphyrins and acetylides connected by $\mathrm{C}_{\mathrm{NHC}}-\mathrm{Au}-\mathrm{C}_{\text {acetylide }}$ bonds.

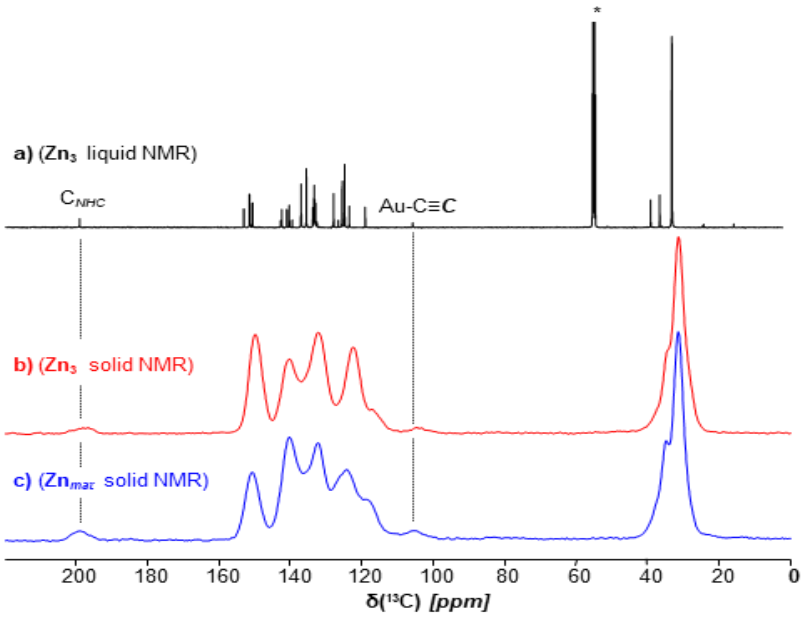

Figure 6.a) ${ }^{13} \mathrm{C}\left\{{ }^{1} \mathrm{H}\right\}$ solution NMR spectrum of $\mathrm{Zn}_{3}$ in $\mathrm{CD}_{2} \mathrm{Cl}_{2}$ (recorded on a 500 MHz NMR instrument at 298K); b) ${ }^{13} \mathrm{C} C P$ MAS NMR spectrum of $\mathbf{Z n}_{3}$ (recorded with a contact time of $6 \mathrm{~ms}$, on a $600 \mathrm{MHz}$ NMR instrument, and spinning at $25 \mathrm{kHz}$ ) and $\mathrm{c}$ ) ${ }^{13} \mathrm{C} \mathrm{CP} \mathrm{MAS} \mathrm{NMR} \mathrm{spectrum} \mathrm{of} \mathbf{Z n}_{\text {mat }}$ (recorded with a contact
time of $6 \mathrm{~ms}$, on a $600 \mathrm{MHz}$ NMR instrument, and spinning at $25 \mathrm{kHz}$ ).

Then, we evaluated if such MCOPs incorporating zinc(II) porphyrins could be of interest for heterogeneous photocatalysis. Indeed, porphyrins are well known photosensitizers, which can reach the triplet excited state after photoexcitation and intersystem crossing from the singlet excited state. ${ }^{51,52}$ Singlet oxygen $\left({ }^{1} \mathrm{O}_{2}\right)$ is produced from this triplet excited state by triplet-triplet energy transfer with triplet oxygen $\left({ }^{3} \mathrm{O}_{2}\right) \cdot{ }^{53}$ Because it is a very strong oxidative agent, ${ }^{1} \mathrm{O}_{2}$ is able to oxidize a great number of surrounding molecules. Consequently, porphyrins can be used to design photoactive materials for photocatalysis, biomedicine or water remediation. ${ }^{52,52}$ Moreover, the presence of a gold $(\mathrm{I})$ atom at the porphyrin periphery could enhance the ${ }^{1} \mathrm{O}_{2}$ production yield by a heavy atom effect. ${ }^{54-56}$

To probe if $\mathbf{Z} \mathbf{n}_{\text {mat }}$ could be used as a heterogeneous photocatalyst, we first performed solid state UV-Vis absorption spectrophotometry analyses to see if this MCOP is able to absorb light in the visible region. Satisfyingly, the solid UV-Vis spectrum of $\mathbf{Z n}_{\text {mat }}$ shows a strong absorbance of the MCOP ranging from $\sim 300-700 \mathrm{~nm}$ (Figure 5a), an important prerequisite for applications in photocatalysis. Other important issues for developing heterogenous photocatalysts are the surface area and the porosity of the solid materials. Therefore, a nitrogen $\left(\mathrm{N}_{2}\right)$ sorption analysis at $77 \mathrm{~K}$ was performed to analyse the surface area and porosity of $\mathbf{Z} \mathbf{n}_{\text {mat }}$. The surface area was found to be $\sim 274 \mathrm{~m}^{2} \cdot \mathrm{g}^{-1}$ using the Brunauer, Emmett and Teller (BET) equation, in agreement with other MCOPs reported in the literature. ${ }^{33} \mathrm{~A}$ large hysteresis loop associated with a steep $\mathrm{N}_{2}$ uptake at low relative pressure $\left(P / P^{\circ}<0.01\right)$ seems to indicate the presence of micropores according to IUPAC's definitions (see the Electronic Supplementary Information, Figure S49). ${ }^{57}$ However, the average pore-size was evaluated at $\sim 3.1 \mathrm{~nm}$, indicating the presence of both micro- and mesopores in $\mathbf{Z n}_{\text {mat. }}{ }^{20,31,58}$

Preliminary tests were performed to see if $\mathbf{Z} \mathbf{n}_{\text {mat }}$ is able to generate ${ }^{1} \mathrm{O}_{2}$ upon irradiation with visible light. To this aim, 1,3diphenylisobenzofuran (DPBF, $\lambda_{\max }=416 \mathrm{~nm}$ ) was used as ${ }^{1} \mathrm{O}_{2}$ quencher, because they react together through a [4+2] cycloaddition leading to the formation of the colourless $O$ dibenzoylbenzene. This reaction can be easily monitored by UVVis absorption spectroscopy by measuring the decrease in DPBF

Figure 7. a) Chemical oxidation of DPBF with ${ }^{1} \mathrm{O}_{2}$; b) Evolution of the DPBF absorbance from 0 to 35 minutes under irradiation and in the presence of $\mathbf{Z n}_{\text {mat }}$; c) Plot of $\ln \left(A_{0} / A\right)=f(t)$ of DPBF alone (black triangles) and DPBF in presence of 3 mol\% $\mathbf{Z n}_{\text {mat }}$ (purple squares).
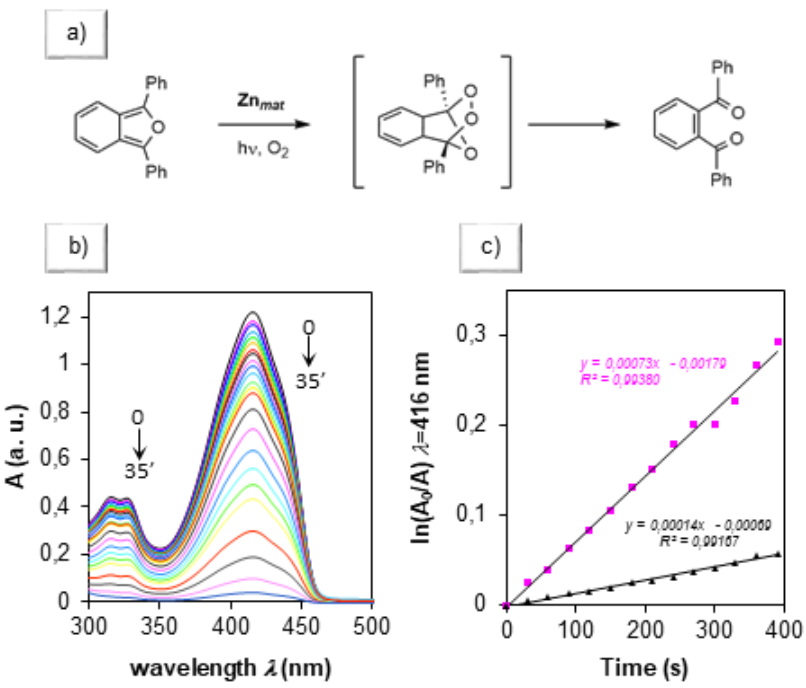
concentration at $415 \mathrm{~nm}$. A DBPF solution in toluene, containing 3 mol\% of insoluble and manually ground $\mathbf{Z} \mathbf{n}_{\text {mat }}$ was irradiated with a halogen lamp for $35 \mathrm{~min}$. The irradiation undoubtedly caused a time dependent decrease of DPBF concentration (Figure 7a). Plots of $\ln \left(A_{0} / A\right)$ vs. time represented in Figure $7 b$ confirm the first order kinetics of this photooxidation process. A $k^{\text {eff }} / k^{\text {obs }}$ ratio of 5 was found (where $k^{\text {eff }}$ and $k^{\text {obs }}$ correspond to apparent kinetic constants in presence and absence of $\mathbf{Z} \mathbf{n}_{\text {mat }}$ respectively), showing that the presence of the heterogeneous photocatalyst $\mathbf{Z} \mathbf{n}_{\text {mat }}$ significantly accelerates the DPBF oxidation. Interestingly, no significant porphyrin leaching could be observed in toluene after irradiation since no absorption bands belonging to free porphyrin species could be detected after 35 minutes of reaction (Figure 7a). The heterogeneous MCOP $\mathbf{Z} \mathbf{n}_{\text {mat }}$ could be recovered by filtration and reused as photocatalyst without any loss of activity. Complementary kinetic and spectroscopic studies will nevertheless be needed to fully assess the recyclability of these heterogeneous MCOPs.

\section{Conclusion}

Janus bis(NHCs) ligands with a porphyrin core and two linearly NHC heads fused to two opposite pyrroles were used for the preparation of molecular trinuclear metal complexes (one metal in the porphyrin core and the two others anchored onto the peripheral NHCs). We notably prepared nickel(II) and zinc(II) porphyrins with two peripheral NHC gold(I) chloride complexes. We also investigated the substitution of chloride ligands by acetylides, allowing the preparation of molecular species containing several porphyrins and metal ions without any complex purification procedures. A representative example is the hexanuclear complex $\mathbf{Z n}_{\mathbf{3}}$ containing three zinc(II) porphyrins and three gold(I) complexes. With these building blocks in hand, we performed the synthesis of heterogeneous main-chain organometallic polymers where metalloporphyrins and polyacetylides are connected through the formation of $\mathrm{C}_{\mathrm{NHC}}-\mathrm{Au}-\mathrm{C}_{\text {acetylide }}$ bonds. One of these materials, namely $\mathbf{Z} \mathbf{n}_{\text {mat }}$, was used as heterogeneous photocatalyst for the production of ${ }^{1} \mathrm{O}_{2}$ upon irradiation with visible light. These heterogeneous porous materials appear as promising candidates for different applications like water remediation, for example.

\section{Conflicts of interest}

There are no conflicts to declare

\section{Acknowledgements}

We warmly thank Dr. Simon Pascal for kind proofreading, as well as Dr. Angel Escamilla-Perez, Dr. Clarence Charnay and Dr. Bertrand Rebière for their help in performing BET, UV-Vis and EDX analyses, respectively.

\section{Experimental Section}

\section{Materials and methods}

Reactions were performed under argon using oven-dried glassware and Schlenk techniques. Gold complex [AuCl(tht)] was prepared with the procedure described in reference. ${ }^{38}$ Acetone (CHROMASOLV ${ }^{\circledR}$, for HPLC, $299.9 \%$ ) was purchased from Sigma-Aldrich ${ }^{\circledR}$. Dry THF and $\mathrm{CH}_{2} \mathrm{Cl}_{2}$ were obtained by a solvent purification system PureSolve MD5 from Innovative Technology. Preparative purifications were performed by silica gel flash column chromatography (Merck ${ }^{\circledR}$ 40-60 $\mu \mathrm{M}$ ). Technical grade solvents were used as eluents in the chromatography and crystallization purifications. ${ }^{1} \mathrm{H},{ }^{13} \mathrm{C}\left\{{ }^{1} \mathrm{H}\right\}$ as well as ${ }^{1} \mathrm{H}$ DOSY NMR experiments were recorded on a Bruker Avance III HD $400 \mathrm{MHz}$ spectrometer equipped with $\mathrm{BBI}$ probe or on a Bruker Avance III $500 \mathrm{MHz}$ spectrometer equipped with Helium BBO Cryoprobe. ${ }^{1} \mathrm{H}$ and ${ }^{13} \mathrm{C}\left\{{ }^{1} \mathrm{H}\right\}$ NMR spectra were calibrated to TMS on the basis of the relative chemical shift of the solvent used as an internal standard. Abbreviations used for ${ }^{1} \mathrm{H}$ NMR spectra are as follows: s singlet, $d$ doublet. Solid state NMR experiments were performed at $14.1 \mathrm{~T}$ using a VNMRS-600 MHz instrument equipped with a Varian T3 HXY $1.6 \mathrm{~mm}$ triple resonance probe, spinning at $25 \mathrm{kHz} .{ }^{1} \mathrm{H}-{ }^{13} \mathrm{C}$ CPMAS (Cross Polarization Magic Angle Spinning) NMR experiments were performed using a 2.5 $\mu \mathrm{s}^{1} \mathrm{H}$ excitation pulse, followed by a $6.0 \mathrm{~ms}$ contact time, and applying spinal-64 ${ }^{1} \mathrm{H}$ decoupling during acquisition. The recycle delay was set to $0.8 \mathrm{~s}$, and the number of transients acquired ranged from 4100 to 17110 , depending on the sample. ${ }^{13} \mathrm{C}$ chemical shifts were referenced externally to adamantane (high-frequency ${ }^{13} \mathrm{C}$ shift at $38.5 \mathrm{ppm}$ ). UV-Vis absorption spectra in solution were recorded in $\mathrm{CH}_{2} \mathrm{Cl}_{2}$ with a JASCO V-750 UV-Visible-NIR spectrophotometer in quartz cells of $10 \mathrm{~mm}$ (Hellma). UV-Vis absorption spectra in the solid state were recorded using a $60 \mathrm{~mm}$ integrating sphere. High-resolution mass spectra (HRMS) were recorded on ESI-TOF Q instruments in positive mode or on a MALDI-TOF spectrometer in positive mode using dithranol as a matrix.

\section{Synthetic procedures}

Synthesis of porphyrin Ni-I 2 . Porphyrin Ni-Imi 2 (120 mg, $1.2 \times$ $10^{-4}$ mol, 1 equiv.) was dissolved in $20 \mathrm{~mL}$ of DMF. Then, $\mathrm{K}_{2} \mathrm{CO}_{3}$ ( $0.034 \mathrm{mg}, 2.4 \times 10^{-4} \mathrm{~mol}, 2$ equiv.) and $\mathrm{Mel}(10 \mathrm{~mL}$, large excess) were added. The solution was stirred at room temperature for $48 \mathrm{~h}$. Afterwards, DMF was removed under reduced pressure, and the crude product was purified by silica gel chromatography ( $\mathrm{SiO}_{2}$; eluent from $\mathrm{CH}_{2} \mathrm{Cl}_{2}$ to $\mathrm{CH}_{2} \mathrm{Cl}_{2} / \mathrm{MeOH}$ 95:5). Crystallization from $\mathrm{CH}_{2} \mathrm{Cl}_{2} / n$-Hexane afforded $\mathbf{N i - I _ { 2 }}$ as red needles in $95 \%$ yield (146 mg). ${ }^{1} \mathrm{H}$ NMR (400 MHz, $\mathrm{CD}_{2} \mathrm{Cl}_{2}$ ): $\delta 10.79$ (s, 2H, $\mathrm{H}_{\text {imidazolium), }}$ ), $8.60\left(\mathrm{~s}, 4 \mathrm{H}, \mathrm{H}_{\text {pyrr }}\right), 8.13\left(\mathrm{~d}, 8 \mathrm{H}, \mathrm{H}_{\text {Ar meso }}, 3^{3} \mathrm{H}_{\mathrm{H}}=8.3 \mathrm{~Hz}\right), 7.80(\mathrm{~d}, 8 \mathrm{H}$, $\left.\mathrm{H}_{\text {Ar meso, }}{ }^{3} \mathrm{~J}_{\mathrm{H}-\mathrm{H}}=8.3 \mathrm{~Hz}\right), 3.20\left(\mathrm{~s}, 12 \mathrm{H}, \mathrm{H}_{\mathrm{NMe}}\right), 1.56\left(\mathrm{~s}, 36 \mathrm{H}, \mathrm{H}_{t \mathrm{Bu}}\right)$ ppm. ${ }^{13} \mathrm{C}\left\{{ }^{1} \mathrm{H}\right\}$ NMR $\left(125.7 \mathrm{MHz}, \mathrm{CD}_{2} \mathrm{Cl}_{2}\right): \delta 154.3,147.0,145.1$, 139.0, 136.8, 135.5, 133.8, 128.6, 126.2, 118.9, 36.3, 35.5, 31.6 ppm. UV Vis $\left(\mathrm{CH}_{2} \mathrm{Cl}_{2}\right): \lambda_{\max }(\log \varepsilon)=422$ (5.4), 540 (4.2), 574 (3.8 L. $\left.\mathrm{mol}^{-1} . \mathrm{cm}^{-1}\right) \mathrm{nm}$. MS (ESI-TOF $\left.{ }^{+}\right): \mathrm{m} / z$ calcd for $\mathrm{C}_{66} \mathrm{H}_{70} \mathrm{~N}_{8} \mathrm{Ni}[\mathrm{M}-$ $21]^{2+} 516.3$, found 516.3 .

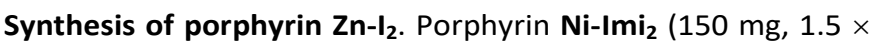
$10^{-4}$ mol, 1 equiv.) was dissolved in a $\mathrm{H}_{2} \mathrm{SO}_{4} /$ TFA mixture (3:10 
$\mathrm{mL}$ ) and stirred at room temperature. The mixture turned green. After 30 minutes, $\mathrm{CHCl}_{3}(100 \mathrm{~mL})$ was added. Then, the mixture was poured on ice and neutralized with $\mathrm{K}_{2} \mathrm{CO}_{3}$ until the reaction mixture turned purple. Afterwards, the organic layer was washed three times with water and dried over $\mathrm{MgSO}_{4}$. The solvent was then evaporated and the residue was dissolved in a $\mathrm{CHCl}_{3} / \mathrm{MeOH}$ mixture $(30: 5 \mathrm{~mL})$ and $\mathrm{Zn}(\mathrm{OAc})_{2} .2 \mathrm{H}_{2} \mathrm{O}(50 \mathrm{mg}, 2.3$ $\times 10^{-4} \mathrm{~mol}, 1.5$ equiv.) was added. The latter mixture was heated at $45^{\circ} \mathrm{C}$ for 1 hour. Once the metalation was complete, the solvents were evaporated and the crude product was purified by silica gel chromatography $\left(\mathrm{SiO}_{2}\right.$; eluent from $\mathrm{CHCl}_{3}$ to $\mathrm{CHCl}_{3}$ /acetone 97:3). Crystallization from $\mathrm{CHCl}_{3} / n$-hexane afforded $\mathbf{Z n}-\mathbf{I m i}_{2}$ as a purple powder in $65 \%$ yield $(98 \mathrm{mg}$ ). This compound was directly engaged in the methylation process by dissolving it in a $\mathrm{CHCl}_{3}$ /acetone mixture $(1: 1,15 \mathrm{~mL})$ with iodomethane $\left(5 \mathrm{~mL}\right.$, large excess) and $\mathrm{K}_{2} \mathrm{CO}_{3(\mathrm{~s})}(27 \mathrm{mg}, 2.0 \times 10$ ${ }^{4} \mathrm{~mol}, 2$ equiv.). This reaction was stirred at room temperature for 48 hours. Then, solvents were evaporated and the crude product was purified by silica gel chromatography $\left(\mathrm{SiO}_{2}\right.$; eluent from $\mathrm{CHCl}_{3}$ to $\mathrm{CHCl}_{3}$ /acetone 3:7). Crystallization from $\mathrm{CHCl}_{3} / n$ hexane afforded $\mathbf{Z n}-\mathbf{I}_{2}$ as a green powder in $34 \%$ yield ( $44 \mathrm{mg}$ ). ${ }^{1} \mathrm{H}$ NMR $\left(500 \mathrm{MHz}, \mathrm{CDCl}_{3}, 298 \mathrm{~K}\right): \delta 10.05$ (s, $2 \mathrm{H}, \mathrm{H}_{\text {imidazolium }), 8.34}$ (s, 4H, $\left.\mathrm{H}_{\text {pyrr }}\right), 8.15$ (bs, 8H, $\left.\mathrm{H}_{\text {Ar meso }}\right), 7.77$ (s, 8H, $\left.\mathrm{H}_{\text {Ar meso }}\right), 2.83$ (s, $\left.12 \mathrm{H}, \mathrm{H}_{\mathrm{NMe}}\right), 1.56\left(\mathrm{~s}, 36 \mathrm{H}, \mathrm{H}_{t \mathrm{Bu}}\right) \mathrm{ppm} .{ }^{13} \mathrm{C}\left\{{ }^{1} \mathrm{H}\right\}$ NMR $(125.7 \mathrm{MHz}$, $\left.\mathrm{CDCl}_{3}, 298 \mathrm{~K}\right): \delta 152.2,150.0,143.1,140.5,139.7,136.7,132.3$, 132.0, 124.8, 118.5, 35.2, 35.1, $31.8 \mathrm{ppm}$. UV/Vis $\left(\mathrm{CHCl}_{3}\right): \lambda_{\max }$ $(\log \varepsilon)=449(5.2), 585(3.9), 633\left(3.8 \mathrm{~L} \mathrm{~mol}^{-1} \mathrm{~cm}^{-1}\right) \mathrm{nm}$. MS (ESITOF ${ }^{+}$): $\mathrm{m} / z$ calcd for $\mathrm{C}_{66} \mathrm{H}_{70} \mathrm{~N}_{8} \mathrm{Zn} 519.3$ [M-2I] ${ }^{2+}$, found 519.3 .

Synthesis of complex [NiAuPh]. A solution of phenylacetylene $\left(4.9 \times 10^{-3} \mathrm{M}\right)$ was prepared in THF. Then, $3.8 \mathrm{~mL}\left(1.8 \times 10^{-5} \mathrm{~mol}\right.$, 1.1 equiv.) of the later solution were added to a Schlenk tube containing porphyrin [NiAuCl] (20 mg, $1.7 \times 10^{-5} \mathrm{~mol}, 1$ equiv.). After a final addition of a $0.25 \mathrm{M} \mathrm{KOH}$ solution in $\mathrm{MeOH}(80 \mu \mathrm{L}$, $2.0 \times 10^{-5}, 1.1$ equiv.), the reaction mixture was stirred at room temperature. After $24 \mathrm{~h}$, the solvent was evaporated. Crystallization from $\mathrm{CH}_{2} \mathrm{Cl}_{2} / \mathrm{MeOH}$ afforded [NiAuPh] in $66 \%$ yield as a red powder (14 mg). ${ }^{1} \mathrm{H}$ NMR $\left(400 \mathrm{MHz}, \mathrm{CD}_{2} \mathrm{Cl}_{2}\right): \delta 8.71$ $\left(\mathrm{s}, 2 \mathrm{H}, \mathrm{H}_{\text {pyrr }}\right), 8.69\left(\mathrm{~d}, 2 \mathrm{H}, \mathrm{H}_{\text {pyrr, }},{ }^{3} \mathrm{H}_{\mathrm{H}-\mathrm{H}}=5 \mathrm{~Hz}\right), 8.67\left(\mathrm{~d}, 2 \mathrm{H}, \mathrm{H}_{\text {pyrr }},{ }^{3} \mathrm{H}_{\mathrm{H}-}\right.$ $\mathrm{H}=5 \mathrm{~Hz}), 8.07\left(\mathrm{~d}, 4 \mathrm{H}, \mathrm{H}_{\text {Ar meso }}{ }^{3} \mathrm{~J}_{\mathrm{H}-\mathrm{H}}=8.3 \mathrm{~Hz}\right), 7.97\left(\mathrm{~d}, 4 \mathrm{H}, \mathrm{H}_{\text {Ar meso }}\right.$, $\left.3 J_{\mathrm{H}-\mathrm{H}}=8.3 \mathrm{~Hz}\right), 7.79\left(\mathrm{~d}, 4 \mathrm{H}, \mathrm{H}_{\text {Ar meso }},{ }^{3} \mathrm{~J}_{\mathrm{H}-\mathrm{H}}=8.3 \mathrm{~Hz}\right), 7.75(\mathrm{~d}, 4 \mathrm{H}$, $\left.\mathrm{H}_{\text {Ar meso }},{ }^{3} \mathrm{H}_{\mathrm{H}-\mathrm{H}}=8.3 \mathrm{~Hz}\right), 7.35\left(\mathrm{~m}, 2 \mathrm{H}, \mathrm{H}_{\mathrm{Ph}}\right), 7.26-7.13\left(\mathrm{~m}, 3 \mathrm{H}, \mathrm{H}_{\mathrm{Ph}}\right)$ $3.18\left(\mathrm{~s}, 6 \mathrm{H}, \mathrm{H}_{\mathrm{NMe}}\right), 1.56\left(\mathrm{~s}, 18 \mathrm{H}, \mathrm{H}_{t \mathrm{Bu}}\right), 1.54\left(\mathrm{~s}, 18 \mathrm{H}, \mathrm{H}_{t \mathrm{Bu}}\right) \mathrm{ppm}$ ${ }^{13} \mathrm{C}\left\{{ }^{1} \mathrm{H}\right\}$ NMR $\left(125.7 \mathrm{MHz}, \mathrm{CD}_{2} \mathrm{Cl}_{2}\right): \delta 198.7\left(\mathrm{C}_{\mathrm{NHC}}\right), 153.3,151.7$, $145.2,144.3,143.7,141.3,138.3,137.7,135.7,134.4,132.9$, $132.7,132.5,132.4,130.6,128.5,127.8,126.7,126.7,125.6$, 124.7, 121.0, 116.7, 105.0, 37.9, 35.5, 35.3, 31.9, 31.8 ppm. IR (FT-ATR): $v_{\mathrm{C} \equiv \mathrm{C}}=2109 \mathrm{~cm}^{-1}$. UV Vis $\left(\mathrm{CH}_{2} \mathrm{Cl}_{2}\right): \lambda_{\max }(\log \varepsilon)=228$ (4.8), 280 (4.9), 426 (5.3), 537 (4.3), $571 \mathrm{~s}\left(3.9\right.$ L.mol-1. $\left.\mathrm{cm}^{-1}\right) \mathrm{nm}$. HR-MS $\left(\right.$ ESI-TOF $\left.{ }^{+}\right): \mathrm{m} / \mathrm{z}$ calcd for $\mathrm{C}_{71} \mathrm{H}_{69} \mathrm{AuN}_{6} \mathrm{Ni}[\mathrm{M}]^{\bullet+} 1260.4603$, found 1260.4597.

Synthesis of complex $\mathbf{N i}_{2}$. A solution of 1,4-diethynylbenzene $\left(2.6 \times 10^{-3} \mathrm{M}\right)$ was prepared in THF. Then, $4.3 \mathrm{~mL}\left(1.12 \times 10^{-5}\right.$ mol, 0.45 equiv.) of the later solution were added to a Schlenk tube containing porphyrin [NiAuCl] $\left(30 \mathrm{mg}, 2.5 \times 10^{-5} \mathrm{~mol}, 1\right.$ equiv.). After a final addition of a $0.25 \mathrm{M} \mathrm{KOH}$ solution in $\mathrm{MeOH}$ (224 $\mu \mathrm{L}, 5.6 \times 10^{-5} \mathrm{~mol}, 5$ equiv.), the reaction mixture was stirred at room temperature. After $48 \mathrm{~h}$ the solvent was evaporated. Crystallization from $\mathrm{CH}_{2} \mathrm{Cl}_{2} / \mathrm{MeOH}$ afforded $\mathbf{N i}_{2}$ in $95 \%$ yield as a red powder (26.1 mg). ${ }^{1} \mathbf{H}$ NMR (400 MHz, $\left.\mathrm{CD}_{2} \mathrm{Cl}_{2}\right)$ : $\delta 8.71\left(\mathrm{~s}, 4 \mathrm{H}, \mathrm{H}_{\text {pyrr }}\right), 8.69\left(\mathrm{~d}, 4 \mathrm{H}, \mathrm{H}_{\text {pyrr }}{ }^{3} J_{\mathrm{H}-\mathrm{H}}=5 \mathrm{~Hz}\right), 8.67(\mathrm{~d}, 4 \mathrm{H}$, $\left.\mathrm{H}_{\text {pyrr, }}{ }^{3} \mathrm{~J}_{\mathrm{H}-\mathrm{H}}=5 \mathrm{~Hz}\right), 8.08\left(\mathrm{~d}, 8 \mathrm{H}, \mathrm{H}_{\text {Ar meso }},{ }^{3} \mathrm{~J}_{\mathrm{H}-\mathrm{H}}=8.3 \mathrm{~Hz}\right), 7.97(\mathrm{~d}, 8 \mathrm{H}$, $\left.\mathrm{H}_{\text {Ar meso, }}{ }^{3} \mathrm{~J}_{\mathrm{H}-\mathrm{H}}=8.3 \mathrm{~Hz}\right), 7.79\left(\mathrm{~d}, 8 \mathrm{H}, \mathrm{H}_{\text {Ar meso, }}{ }^{3} \mathrm{~J}_{\mathrm{H}-\mathrm{H}}=8.3 \mathrm{~Hz}\right), 7.75$ $\left(\mathrm{d}, 8 \mathrm{H}, \mathrm{H}_{\text {Ar meso }},{ }^{3} \mathrm{~J}_{\mathrm{H}-\mathrm{H}}=8.3 \mathrm{~Hz}\right), 7.21\left(\mathrm{~s}, 4 \mathrm{H}, \mathrm{H}_{\mathrm{Ph}}\right), 3.18(\mathrm{~s}, 12 \mathrm{H}$, $\left.\mathrm{H}_{\mathrm{NMe}}\right), 1.56\left(\mathrm{~s}, 36 \mathrm{H}, \mathrm{H}_{t \mathrm{Bu}}\right), 1.55\left(\mathrm{~s}, 36 \mathrm{H}, \mathrm{H}_{t \mathrm{Bu}}\right) \mathrm{ppm} .{ }^{13} \mathrm{C}\left\{{ }^{1} \mathrm{H}\right\}$ NMR $\left(125.7 \mathrm{MHz}, \mathrm{CD}_{2} \mathrm{Cl}_{2}\right): \delta 198.6\left(\mathrm{C}_{\mathrm{NHC}}\right), 153.3,151.7,145.2,144.3$, $143.7,141.3,138.3,137.6,135.7,134.4,132.9,132.7,132.5$, 132.0, 127.8, 125.7, 124.7, 124.4, 120.9, 116.7, 37.9, 35.5, 35.3, 31.9, $31.8 \mathrm{ppm}$. IR (FT-ATR): $v_{\mathrm{C}=\mathrm{C}}=2109 \mathrm{~cm}^{-1}$. UV Vis $\left(\mathrm{CH}_{2} \mathrm{Cl}_{2}\right)$ : $\lambda_{\max }(\log \varepsilon)=311$ (4.8), 328 (4.9), 426 (5.5), 537 (4.5), $572 \mathrm{~s} \mathrm{(4} \mathrm{L.}$ $\mathrm{mol}^{-1}$. cm $\mathrm{cm}^{-1}$ ) nm. MS (MALDI-TOF $\left.{ }^{+}\right): \mathrm{m} / \mathrm{z}$ calcd for $\mathrm{C}_{136} \mathrm{H}_{132} \mathrm{Au}_{2} \mathrm{~N}_{12} \mathrm{Ni}_{2}[\mathrm{M}]^{\bullet+}$ 2242.8736, found 2242.8.

Synthesis of complex $\mathrm{Ni}_{3}$. A solution of 1,3,5-tri-(4ethynylphenyl)benzene $\left(1.8 \times 10^{-3} \mathrm{M}\right)$ was prepared in THF. Then, $4.3 \mathrm{~mL}\left(2.6 \times 10^{-5} \mathrm{~mol}, 0.3\right.$ equiv.) of the later solution were added to a Schlenk tube containing porphyrin [NiAuCl] (30 $\mathrm{mg}, 2.5 \times 10^{-5} \mathrm{~mol}, 1$ equiv.). After a final addition of a $0.25 \mathrm{M}$ $\mathrm{KOH}$ solution in $\mathrm{MeOH}\left(188 \mu \mathrm{L}, 4.5 \times 10^{-5} \mathrm{~mol}, 2\right.$ equiv.), the reaction mixture was stirred at room temperature. After $72 \mathrm{~h}$ a red precipitate appeared. The title compound was isolated after addition of fresh THF (3-5 mL), followed by vacuum filtration in $75 \%$ yield as a red powder $(22.6 \mathrm{mg}) .{ }^{1} \mathbf{H}$ NMR $(400 \mathrm{MHz}$, $\left.\mathrm{CD}_{2} \mathrm{Cl}_{2}\right): \delta 8.71\left(\mathrm{~s}, 6 \mathrm{H}, \mathrm{H}_{\text {pyrr }}\right), 8.70\left(\mathrm{~d}, 6 \mathrm{H}, \mathrm{H}_{\text {pyrr, }},{ }^{3} J_{\mathrm{H}-\mathrm{H}}=5 \mathrm{~Hz}\right), 8.68$ $\left(\mathrm{d}, 6 \mathrm{H}, \mathrm{H}_{\text {pyrr }}, 3 J_{\mathrm{H}-\mathrm{H}}=5 \mathrm{~Hz}\right), 8.10\left(\mathrm{~d}, 12 \mathrm{H}, \mathrm{H}_{\text {Ar meso }},{ }^{3} \mathrm{~J}_{\mathrm{H}-\mathrm{H}}=8.3 \mathrm{~Hz}\right)$, $7.97\left(\mathrm{~d}, 12 \mathrm{H}, \mathrm{H}_{\text {Ar meso, }}{ }^{3} \mathrm{~J}_{\mathrm{H}-\mathrm{H}}=8.3 \mathrm{~Hz}\right), 7.81\left(\mathrm{~d}, 12 \mathrm{H}, \mathrm{H}_{\text {Ar meso, }}{ }^{3} \mathrm{~J}_{\mathrm{H}-\mathrm{H}}=\right.$ $8.3 \mathrm{~Hz}), 7.76\left(\mathrm{~s}, 3 \mathrm{H}, \mathrm{H}_{\mathrm{Ph}}\right), 7.75\left(\mathrm{~d}, 12 \mathrm{H}, \mathrm{H}_{\text {Ar meso }},{ }^{3} \mathrm{~J}_{\mathrm{H}-\mathrm{H}}=8.3 \mathrm{~Hz}\right)$, $7.60\left(\mathrm{~d}, 6 \mathrm{H}, \mathrm{H}_{\mathrm{Ph}},{ }^{3} \mathrm{~J}_{\mathrm{H}-\mathrm{H}}=8.3 \mathrm{~Hz}\right), 7.46\left(\mathrm{~d}, 6 \mathrm{H}, \mathrm{H}_{\mathrm{Ph}},{ }^{3} \int_{\mathrm{H}-\mathrm{H}}=8.3 \mathrm{~Hz}\right)$, $3.22\left(\mathrm{~s}, 18 \mathrm{H}, \mathrm{H}_{\mathrm{NMe}}\right), 1.56\left(\mathrm{~s}, 108 \mathrm{H}, \mathrm{H}_{t \mathrm{Bu}}\right) \mathrm{ppm} .{ }^{13} \mathrm{C}\left\{{ }^{1} \mathrm{H}\right\}$ NMR $(125.7$ $\left.\mathrm{MHz}, \mathrm{CD}_{2} \mathrm{Cl}_{2}\right): \delta 198.8\left(\mathrm{C}_{\mathrm{NHC}}\right), 153.5,151.6,145.2,144.3,143.7$, $143.5,142.3,141.7,141.3,139.2(2 \mathrm{C}), 138.4,137.6,135.7$, $134.4,132.8,132.7,132.5,127.8,127.4,126,125.7,124.7$, 123.9, 120.9, 116.7, 38, 35.5, 35.3, 31.9(2C) ppm. IR (FT-ATR): $v_{\mathrm{C}=\mathrm{C}}=2109 \mathrm{~cm}^{-1}$. UV Vis $\left(\mathrm{CH}_{2} \mathrm{Cl}_{2}\right): \lambda_{\max }(\log \varepsilon)=316(5.1), 425$ (5.7), 537 (4.7), $572 \mathrm{~s},\left(4.3 \mathrm{~L}\right.$. mol-1. $\left.\mathrm{cm}^{-1}\right) \mathrm{nm}$. MS (MALDI-TOF ${ }^{+}$): $\mathrm{m} / \mathrm{z}$ calcd for $\mathrm{C}_{219} \mathrm{H}_{208} \mathrm{Au}_{3} \mathrm{~N}_{18} \mathrm{Ni}_{3}[\mathrm{M}+\mathrm{H}]^{+}$3854.3886, found 3854.4.

Synthesis of complex $\mathbf{Z n}_{3}$. A solution of 1,3,5-tris(4ethynylphenyl)benzene $\left(1.8 \times 10^{-3} \mathrm{M}\right)$ was prepared in THF. Then, $4.3 \mathrm{~mL}\left(2.6 \times 10^{-5} \mathrm{~mol}, 0.3\right.$ equiv. $)$ of the later solution were added to a Schlenk tube containing porphyrin [ZnAuCl] (30 $\mathrm{mg}, 2.5 \times 10^{-5} \mathrm{~mol}, 1$ equiv.). After a final addition of a $0.25 \mathrm{M}$ $\mathrm{KOH}$ solution in $\mathrm{MeOH}\left(300 \mu \mathrm{L}, 7.5 \times 10^{-5}\right.$ mol, 3 equiv.), the reaction mixture was stirred at room temperature. After $72 \mathrm{~h}$, a dark purple precipitate appeared. After filtration, the solid was redispersed in fresh $\mathrm{MeOH}(10 \mathrm{~mL})$ and submitted to ultrasounds for $10 \mathrm{~min}$. The title compound was isolated after vacuum filtration in $85 \%$ yield as a purple powder $(27.6 \mathrm{mg}) .{ }^{1} \mathbf{H}$ NMR (400 MHz, $\left.\mathrm{CD}_{2} \mathrm{Cl}_{2}\right): \delta 8.96\left(\mathrm{~d}, 6 \mathrm{H}, \mathrm{H}_{\text {pyrr }},{ }^{3}{ }_{\mathrm{H}-\mathrm{H}}=5 \mathrm{~Hz}\right), 8.95(\mathrm{~s}$, $\left.6 \mathrm{H}, \mathrm{H}_{\text {pyrr }}\right), 8.90\left(\mathrm{~d}, 6 \mathrm{H}, \mathrm{H}_{\text {pyrr }},{ }^{3} \mathrm{H}_{\mathrm{H}-\mathrm{H}}=5 \mathrm{~Hz}\right), 8.21\left(\mathrm{~d}, 12 \mathrm{H}, \mathrm{H}_{\text {Ar meso }}\right.$, $\left.3 J_{\mathrm{H}-\mathrm{H}}=8.3 \mathrm{~Hz}\right), 8.17\left(\mathrm{~d}, 12 \mathrm{H}, \mathrm{H}_{\text {Ar meso }}, 3 \mathrm{~J}_{\mathrm{H}-\mathrm{H}}=8.3 \mathrm{~Hz}\right), 7.82(\mathrm{~s}, 3 \mathrm{H}$, $\left.\mathrm{H}_{\mathrm{Ph}}\right), 7.81\left(\mathrm{~d}, 12 \mathrm{H}, \mathrm{H}_{\text {Ar meso }}{ }^{3} \mathrm{~J}_{\mathrm{H}-\mathrm{H}}=8.3 \mathrm{~Hz}\right), 7.76\left(\mathrm{~d}, 12 \mathrm{H}, \mathrm{H}_{\text {Ar meso, }}\right.$ $\left.{ }^{3} J_{\mathrm{H}-\mathrm{H}}=8.3 \mathrm{~Hz}\right), 7.65\left(\mathrm{~d}, 6 \mathrm{H}, \mathrm{H}_{\mathrm{Ph}},{ }^{3} \mathrm{~J}_{\mathrm{H}-\mathrm{H}}=8.3 \mathrm{~Hz}\right), 7.48\left(\mathrm{~d}, 6 \mathrm{H}, \mathrm{H}_{\mathrm{Ph}}\right.$, $\left.3 J_{\mathrm{H}-\mathrm{H}}=8.3 \mathrm{~Hz}\right), 3.22\left(\mathrm{~s}, 18 \mathrm{H}, \mathrm{H}_{\mathrm{NMe}}\right), 1.62\left(\mathrm{~s}, 54 \mathrm{H}, \mathrm{H}_{t \mathrm{Bu}}\right), 1.57(\mathrm{~s}$, $\left.54 \mathrm{H}, \mathrm{H}_{t \mathrm{Bu}}\right)$ ppm. ${ }^{13} \mathrm{C}\left\{{ }^{1} \mathrm{H}\right\}$ NMR $\left(125.7 \mathrm{MHz}, \mathrm{CD}_{2} \mathrm{Cl}_{2}\right): \delta 199.4$ $\left(\mathrm{C}_{\mathrm{NHC}}\right), 152.9,151.3,151,150.3,142.4,142.2,140.7,140,139.2$, 
$136.7,135.1,133.4,132.9(2 \mathrm{C}), 132.7,132.5,132.1,127.4$ $126.1,125,124.3,122.9,118.4,110.6,105.1,38,35.5,35.4$ 34.7, 32, $31.9 \mathrm{ppm}$. IR (FT-ATR): $v_{\mathrm{C} \equiv \mathrm{C}}=2110 \mathrm{~cm}^{-1}$. UV Vis $\left(\mathrm{CH}_{2} \mathrm{Cl}_{2}\right): \lambda_{\max }(\log \varepsilon)=316(5.3), 428(6.2), 556(4.8), 596 \mathrm{~s},(4.3$ L. $\mathrm{mol}^{-1} . \mathrm{cm}^{-1}$ ) nm. MS (MALDI-TOF $\left.{ }^{+}\right): \mathrm{m} / z$ calcd for $\mathrm{C}_{219} \mathrm{H}_{207} \mathrm{Au}_{3} \mathrm{~N}_{18} \mathrm{Zn}_{3}[\mathrm{M}]^{\bullet+}$ 3878.2307, found 3878.3.

Synthesis of complex $\left[\mathrm{Ni}(\mathrm{AuCl})_{2}\right]$. A solution of the porphyrin $\mathrm{Ni}-\mathrm{I}_{2}$ (60 mg, $4.7 \times 10^{-5}$ mol, 1 equiv.) was prepared in $\mathrm{CH}_{2} \mathrm{Cl}_{2}$ (8 $\mathrm{mL}$ ). Then, $\mathrm{Ag}_{2} \mathrm{O}\left(21.6 \mathrm{mg}, 9.3 \times 10^{-5} \mathrm{~mol}, 2\right.$ equiv.) was added and the reaction mixture was vigorously stirred at room temperature, under an argon atmosphere protected from light. After $6 \mathrm{~h},[\mathrm{AuCl}(\mathrm{tht})]$ ( $29 \mathrm{mg}, 9.3 \times 10^{-5} \mathrm{~mol}, 2$ equiv.) was added and the mixture was stirred for an additional $12 \mathrm{~h}$ period under the same conditions. The reaction was monitored by TLC analysis. When the reaction was complete, the solvent was evaporated and the title compound was purified by column chromatography $\left(\mathrm{SiO}_{2}\right.$; eluent from $\mathrm{CH}_{2} \mathrm{Cl}_{2} / n$-hexane $7: 3$ to $\mathrm{CH}_{2} \mathrm{Cl}_{2}$ ). Crystallization from $\mathrm{CH}_{2} \mathrm{Cl}_{2} / \mathrm{MeOH}$ afforded [Ni(AuCl) ${ }_{2}$ ] as red needles in $66 \%$ yield $(46.3 \mathrm{mg}) .{ }^{1} \mathbf{H}$ NMR $(400 \mathrm{MHz}$, $\left.\mathrm{CD}_{2} \mathrm{Cl}_{2}\right): \delta 8.52\left(\mathrm{~s}, 4 \mathrm{H}, \mathrm{H}_{\text {pyrr }}\right), 8.13\left(\mathrm{~d}, 8 \mathrm{H}, \mathrm{H}_{\text {Ar meso }}, 3{ }^{\mathrm{H}-\mathrm{H}}=8.3 \mathrm{~Hz}\right)$, $7.85\left(\mathrm{~d}, 8 \mathrm{H}, \mathrm{H}_{\text {Ar meso }},{ }^{3} \mathrm{~J}_{\mathrm{H}-\mathrm{H}}=8.3 \mathrm{~Hz}\right), 3.10\left(\mathrm{~s}, 12 \mathrm{H}, \mathrm{H}_{\mathrm{NMe}}\right), 1.55(\mathrm{~s}$, $\left.36 \mathrm{H}, \mathrm{H}_{t \mathrm{Bu}}\right) .{ }^{13} \mathrm{C}\left\{{ }^{1} \mathrm{H}\right\}$ NMR $\left(125.7 \mathrm{MHz}, \mathrm{CD}_{2} \mathrm{Cl}_{2}\right): \delta 182.7,153.6$, $146.8,140.5,137.5,135.6,132.9,129.5,125.9,118.4,38.0$, 35.4, 34.7 ppm. UV Vis $\left(\mathrm{CH}_{2} \mathrm{Cl}_{2}\right): \lambda_{\max }(\log \varepsilon)=432(5.4), 542$ (4.2), 576 (3.7 L. mol ${ }^{-1} . \mathrm{cm}^{-1}$ ) nm. MS (MALDI-TOF $\left.{ }^{+}\right): \mathrm{m} / z$ calcd for $\mathrm{C}_{66} \mathrm{H}_{68} \mathrm{Au}_{2} \mathrm{Cl}_{2} \mathrm{~N}_{8} \mathrm{Ni}[\mathrm{M}]^{\bullet+} 1494.36$, found [M] ${ }^{\bullet+}$ 1494.4.

Synthesis of complex [Ni(AuPh $\left.)_{2}\right]$. A solution of phenylacetylene $\left(4.9 \times 10^{-3} \mathrm{M}\right)$ was prepared in THF. Then, 10.2 $\mathrm{mL}\left(5.0 \times 10^{-5} \mathrm{~mol}, 2.5\right.$ equiv. $)$ of the later solution were added to a Schlenk tube containing [ $\left.\mathrm{Ni}(\mathrm{AuCl})_{2}\right]\left(30 \mathrm{mg}, 2.0 \times 10^{-5} \mathrm{~mol}\right.$, 1 equiv.). After the addition of a $0.25 \mathrm{M} \mathrm{KOH}$ solution in $\mathrm{MeOH}$ ( $800 \mu \mathrm{L}, 20.0 \times 10^{-5}, 10$ equiv), the reaction mixture was stirred at room temperature. After 24 hours, the solvent was evaporated. Crystallization from $\mathrm{CH}_{2} \mathrm{Cl}_{2} / \mathrm{MeOH}$ afforded [ $\mathbf{N i}(\text { AuPh })_{2}$ ] in $80 \%$ yield as a red powder $(26 \mathrm{mg}) .{ }^{1} \mathbf{H}$ NMR (400 $\left.\mathrm{MHz}, \mathrm{CD}_{2} \mathrm{Cl}_{2}, 298 \mathrm{~K}\right): \delta 8.56\left(\mathrm{~s}, 4 \mathrm{H}, \mathrm{H}_{\text {pyrr }}\right), 8.14\left(\mathrm{~d}, 8 \mathrm{H}, \mathrm{H}_{\text {Ar meso }},{ }^{3} \mathrm{~J}_{\mathrm{H}-}\right.$ $\mathrm{H}=8.3 \mathrm{~Hz}), 7.86\left(\mathrm{~d}, 8 \mathrm{H}, \mathrm{H}_{\text {Ar meso }},{ }^{3} \mathrm{~J}_{\mathrm{H}-\mathrm{H}}=8.3 \mathrm{~Hz}\right), 7.33\left(\mathrm{~m}, 4 \mathrm{H}, \mathrm{H}_{\text {Ph }}\right)$, 7.26-7.10 (m, 6H, $\left.\mathrm{H}_{\mathrm{Ph}}\right), 3.14\left(\mathrm{~s}, 12 \mathrm{H}, \mathrm{H}_{\mathrm{NMe}}\right), 1.55\left(\mathrm{~s}, 36 \mathrm{H}, \mathrm{H}_{t \mathrm{Bu}}\right)$ ppm. ${ }^{13} \mathrm{C}\left\{{ }^{1} \mathrm{H}\right\}$ NMR $\left(125.7 \mathrm{MHz}, \mathrm{CD}_{2} \mathrm{Cl}_{2}, 298 \mathrm{~K}\right): \delta 198.4$ (NHC), $153.4,146.6,141.0,137.7,135.6,132.8,132.2,130.4,129.6$, $128.4,126.6,125.9,118.3,104.9,37.6,35.4,31.7 \mathrm{ppm}$. UV Vis $\left(\mathrm{CH}_{2} \mathrm{Cl}_{2}\right): \lambda_{\max }(\log \varepsilon)=435$ (5.5), $544(4.4), 584\left(4.0 \mathrm{~L} \mathrm{~mol}^{-1} \mathrm{~cm}^{-1}\right)$ nm. IR (FT-ATR): $v_{\mathrm{C}=\mathrm{C}}=2115 \mathrm{~cm}^{-1}$. MS (MALDI-TOF $\left.{ }^{+}\right): \mathrm{m} / \mathrm{z}$ calcd for $\mathrm{C}_{82} \mathrm{H}_{80} \mathrm{Au}_{2} \mathrm{~N}_{8} \mathrm{Ni} 1628.5[\mathrm{M}]^{\bullet+}$, found 1626.5.

Synthesis of complex $\left[\mathrm{Zn}(\mathrm{AuCl})_{2}\right]$. A solution of the porphyrin $\mathbf{Z n - I _ { 2 }}$ (45 mg, $3.9 \times 10^{-5} \mathrm{~mol}, 1$ equiv.) was prepared in a $\mathrm{CH}_{2} \mathrm{Cl}_{2} / \mathrm{CHCl}_{3}$ mixture (10/5 mL). Then, $\mathrm{Ag}_{2} \mathrm{O}$ (18 mg, $7.7 \times 10^{-5}$ mol, 2 equiv.) was added, and the reaction mixture was vigorously stirred at room temperature under an argon atmosphere protected from light. After 6 hours, [AuCl(tht)] (25 $\mathrm{mg}, 7.7 \times 10^{-5} \mathrm{~mol}, 2$ equiv.) was added and the mixture was stirred for 12 hours under the same conditions. The reaction was monitored by silica gel TLC analysis. When the reaction was complete, the solvent was evaporated and the title compound was purified by column chromatography $\left(\mathrm{SiO}_{2}\right.$; eluent $\left.\mathrm{CHCl}_{3}\right)$. Crystallization from $\mathrm{CHCl}_{3} / n$-hexane afforded [ $\mathrm{Zn}(\mathrm{AuCl})_{2}$ ] as a green powder in $85 \%$ yield (49 mg). ${ }^{1} \mathbf{H}$ NMR $\left(500 \mathrm{MHz}, \mathrm{CD}_{2} \mathrm{Cl}_{2}\right.$,
$298 \mathrm{~K}): \delta 8.61\left(\mathrm{~s}, 4 \mathrm{H}, \mathrm{H}_{\text {pyrr }}\right), 8.28\left(\mathrm{~d}, 8 \mathrm{H}, \mathrm{H}_{\text {Ar meso, }}{ }^{3} \mathrm{~J}_{\mathrm{H}-\mathrm{H}}=8.3 \mathrm{~Hz}\right)$, $7.85\left(\mathrm{~d}, 8 \mathrm{H}, \mathrm{H}_{\mathrm{Ar} \text { meso }}{ }^{3} \mathrm{~J}_{\mathrm{H}-\mathrm{H}}=8.3 \mathrm{~Hz}\right), 3.04\left(\mathrm{~s}, 12 \mathrm{H}, \mathrm{H}_{\mathrm{NMe}}\right), 1.61(\mathrm{~s}$, $\left.36 \mathrm{H}, \mathrm{H}_{t \mathrm{Bu}}\right) .{ }^{13} \mathrm{C}\left\{{ }^{1} \mathrm{H}\right\}$ NMR $\left(125.7 \mathrm{MHz}, \mathrm{CD}_{2} \mathrm{Cl}_{2}, 298 \mathrm{~K}\right): \delta 182.0$ $\left(\mathrm{C}_{\mathrm{NHC}}\right), 152.8,150.8,141.3,140.1,136.5,132.8,132.4,125.0$, $118.9,37.7,35.3,31.8 \mathrm{ppm}$. UV/vis $\left(\mathrm{CHCl}_{3}\right): \lambda_{\max }(\log \varepsilon)=444$ (5.1), 574 (3.7), $622\left(3.5 \mathrm{~L} \mathrm{~mol}^{-1} \mathrm{~cm}^{-1}\right) \mathrm{nm}$. MS (MALDI-TOF $\left.{ }^{+}\right): \mathrm{m} / \mathrm{z}$ calcd for $\mathrm{C}_{66} \mathrm{H}_{68} \mathrm{Au}_{2} \mathrm{Cl}_{2} \mathrm{~N}_{8} \mathrm{Zn}[\mathrm{M}]^{\bullet+} 1500.35$, found $1500.3[\mathrm{M}]{ }^{\bullet+}$. Synthesis of material $\mathbf{N i}_{\text {mat }}$. A solution of 1,3,5-tris(4ethynylphenyl)benzene $\left(1.8 \times 10^{-3} \mathrm{M}\right)$ was prepared in THF. Then, $7.5 \mathrm{~mL}\left(1.3 \times 10^{-5} \mathrm{~mol}, 1\right.$ equiv. $)$ of the later solution were added to a Schlenk tube containing [ $\left.\mathrm{Ni}(\mathrm{AuCl})_{2}\right](30 \mathrm{mg}, 2.0 \times 10$ ${ }^{5} \mathrm{~mol}, 1.5$ equiv.). After the addition of a $0.25 \mathrm{M} \mathrm{KOH}$ solution in $\mathrm{MeOH}\left(800 \mu \mathrm{L}, 2.0 \times 10^{-4} \mathrm{~mol}, 15\right.$ equiv.), the reaction mixture was stirred for 6 hours at $50^{\circ} \mathrm{C}$ and a red precipitate appeared. The title compound was isolated by vacuum filtration in $74 \%$ yield as a red powder (25 mg). Elem. Anal. calc (\%) for $\left(\mathrm{C}_{129} \mathrm{H}_{117} \mathrm{Au}_{3} \mathrm{~N}_{12} \mathrm{Ni}_{1.5}\right)_{\mathrm{n}}: \mathrm{C} 61.64, \mathrm{H}$ 4.70, N 6.68, found $\mathrm{C} 60.3, \mathrm{H}$ 4.75, N 6.35. IR (ATR): $v_{C=C}=2100 \mathrm{~cm}^{-1}$.

Synthesis of material $\mathbf{Z n}_{\text {mat }}$. A solution of 1,3,5-tris(4ethynylphenyl)benzene $\left(1.8 \times 10^{-3} \mathrm{M}\right)$ was prepared in THF. Then, $7.5 \mathrm{~mL}\left(1.3 \times 10^{-5} \mathrm{~mol}, 1\right.$ equiv. $)$ of the later solution were added to a Schlenk tube containing the $\left[\mathrm{Zn}(\mathrm{AuCl})_{2}\right]$ porphyrin ( $30 \mathrm{mg}, 2.0 \times 10^{-5} \mathrm{~mol}, 1.5$ equiv.). After the addition of a 0.25 $\mathrm{M} \mathrm{KOH}$ solution in $\mathrm{MeOH}\left(800 \mu \mathrm{L}, 2.0 \times 10^{-4} \mathrm{~mol}, 15\right.$ equiv.), the reaction mixture was stirred for 4 hours at $50^{\circ} \mathrm{C}$ and a dark purple precipitate appeared. The title compound was isolated by vacuum filtration in $83 \%$ yield as a red powder ( $28 \mathrm{mg}$ ). Elem. Anal. calc (\%) for $\left(\mathrm{C}_{129} \mathrm{H}_{117} \mathrm{Au}_{3} \mathrm{~N}_{12} \mathrm{Zn}_{1.5}\right)_{\mathrm{n}}: \mathrm{C} 61.42, \mathrm{H} 4.68, \mathrm{~N} 6.66$, found C 58.60, H 4.89, N 6.80. IR (ATR): $v_{C} \equiv C=2104 \mathrm{~cm}^{-1}$.

Oxidation procedure. A DPBF solution $\left(6 \times 10^{-4} \mathrm{M}\right)$ was prepared in toluene $(200 \mathrm{~mL})$. Then, $3 \mathrm{mg}$ of manually ground $\mathbf{Z} \mathbf{n}_{\text {mat }}$ material ( 3 mol.\% of porphyrins) were added. Afterwards, the mixture was vigorously stirred and irradiated (halogen lamp, $500 \mathrm{~W}$ ) for $35 \mathrm{~min}$. Aliquots were analysed using UV-Vis absorption spectroscopy ( $1 \mathrm{~mm}$ quartz cells) every $30 \mathrm{~s}, 1 \mathrm{~min}$, $3 \mathrm{~min}$ or $5 \mathrm{~min}$.

\section{Notes and references}

1 P. de Frémont, N. Marion and S. P. Nolan, Coord. Chem. Rev., 2009, 253, 862-892.

2 M. N. Hopkinson, C. Richter, M. Schedler and F. Glorius, Nature, 2014, 510, 485-496.

3 L. Cavallo, A. Correa, C. Costabile and H. Jacobsen, J. Organomet. Chem., 2005, 690, 5407-5413.

4 C. M. Crudden and D. P. Allen, Coord. Chem. Rev., 2004, 248, 2247-2273.

5 H. Jacobsen, A. Correa, A. Poater, C. Costabile and L. Cavallo, Coord. Chem. Rev., 2009, 253, 687-703.

6 F. E. Hahn, Chem. Rev., 2018, 118, 9455-9456.

7 A. T. Biju, N-Heterocyclic Carbenes in Organocatalysis, John Wiley \& Sons, 2019.

8 W. A. Herrmann and C. Köcher, Angew. Chem. Int. Ed. Engl., 1997, 36, 2162-2187.

9 C. A. Smith, M. R. Narouz, P. A. Lummis, I. Singh, A. Nazemi, C.H. Li and C. M. Crudden, Chem. Rev., 2019, 119, 4986-5056.

10 Q. Xu, W.-L. Duan, Z.-Y. Lei, Z.-B. Zhu and M. Shi, Tetrahedron, 2005, 61, 11225-11229. 
11 J. A. Mata, M. Poyatos and E. Peris, Coord. Chem. Rev., 2007, 251, 841-859.

12 D. Munz and T. Strassner, Angew. Chem. Int. Ed., 2014, 53, 2485-2488.

13 P. D. W. Boyd, A. J. Edwards, M. G. Gardiner, C. C. Ho, M.-H. Lemée-Cailleau, D. S. McGuinness, A. Riapanitra, J. W. Steed, D. N. Stringer and B. F. Yates, Angew. Chem. Int. Ed., 2010, 49, 6315-6318.

14 C. D. V. Jr, V. M. Lynch and C. W. Bielawski, Dalton Trans., 2009, 7253-7261.

15 D. M. Khramov, A. J. Boydston and C. W. Bielawski, Angew. Chem. Int. Ed., 2006, 45, 6186-6189.

16 D. Tapu, Z. McCarty and C. McMillen, Chem. Commun., 2014, 50, 4725-4728.

17 H. Valdés, M. Poyatos and E. Peris, Organometallics, 2015, 34, 1725-1729.

18 D. G. Gusev and E. Peris, Dalton Trans., 2013, 42, 7359-7364.

19 J.-Q. Liu, X.-X. Gou and Y.-F. Han, Chem. - Asian J., 2018, 13, 2257-2276.

20 A. A. Danopoulos and P. Braunstein, Chem. Commun., 2014, 50, 3055-3057.

21 M. G. Gardiner and C. C. Ho, Coord. Chem. Rev., 2018, 375, 373388.

22 S. Gonell, M. Poyatos and E. Peris, Chem. - Eur. J., 2014, 20, 9716-9724.

23 A. Prades, E. Peris and M. Alcarazo, Organometallics, 2012, 31, 4623-4626.

24 F. E. Hahn, C. Radloff, T. Pape and A. Hepp, Organometallics, 2008, 27, 6408-6410.

25 A. Gutiérrez-Blanco, S. Ibáñez, F. E. Hahn, M. Poyatos and E. Peris, Organometallics, 2019, 38, 4565-4569.

26 N. Sinha and F. E. Hahn, Acc. Chem. Res., 2017, 50, 2167-2184.

27 D. Nuevo, M. Poyatos and E. Peris, Organometallics, 2018, 37, 3407-3411.

28 R. Visbal and M. C. Gimeno, Chem. Soc. Rev., 2014, 43, 35513574.

29 L. Mercs and M. Albrecht, Chem. Soc. Rev., 2010, 39, 19031912.

30 K. A. Williams, A. J. Boydston and C. W. Bielawski, Chem. Soc. Rev., 2007, 36, 729-744.

31 K. S. Song, D. Kim, K. Polychronopoulou and A. Coskun, ACS Appl. Mater. Interfaces, 2016, 8, 26860-26867.

32 C. Zhang, J.-J. Wang, Y. Liu, H. Ma, X.-L. Yang and H.-B. Xu, Chem. - Eur. J., 2013, 19, 5004-5008.

33 S. Gonell, M. Poyatos and E. Peris, Chem. - Eur. J., 2014, 20, $5746-5751$.

34 S. Richeter, A. Hadj-Aïssa, C. Taffin, A. van der Lee and D. Leclercq, Chem. Commun., 2007, 2148-2150.

35 J.-F. Lefebvre, J.-F. Longevial, K. Molvinger, S. Clément and S. Richeter, Comptes Rendus Chim., 2016, 19, 94-102.

36 J.-F. Lefebvre, M. Lo, D. Leclercq and S. Richeter, Chem. Commun., 2011, 47, 2976-2978.

37 C. Rose, A. Lebrun, S. Clément and S. Richeter, Chem. Commun., 2018, 54, 9603-9606.

38 J.-F. Longevial, A. Langlois, A. Buisson, C. H. Devillers, S. Clément, A. van der Lee, P. D. Harvey and S. Richeter, Organometallics, 2016, 35, 663-672.
39 J.-F. Longevial, K. El Cheikh, D. Aggad, A. Lebrun, A. van der Lee, F. Tielens, S. Clément, A. Morère, M. Garcia, M. Gary-Bobo and S. Richeter, Chem. - Eur. J., 2017, 23, 14017-14026.

40 F. Caporaletti, J. Rubio-Magnieto, M. Lo, J.-F. Longevial, C. Rose, S. Clément, A. van der Lee, M. Surin and S. Richeter, J. Porphyr. Phthalocyanines, 2019, DOI 10.1142/S1088424619501128.

41 M. Lo, J.-F. Lefebvre, D. Leclercq, A. van der Lee and S. Richeter, Org. Lett., 2011, 13, 3110-3113.

42 M. Lo, J.-F. Lefebvre, N. Marcotte, C. Tonnelé, D. Beljonne, R. Lazzaroni, S. Clément and S. Richeter, Chem. Commun., 2012, 48, 3460-3462.

43 M. Brill, A. Collado, D. B. Cordes, A. M. Z. Slawin, M. Vogt, H. Grützmacher and S. P. Nolan, Organometallics, 2015, 34, 263274.

44 P. Hikisz, Ł. Szczupak, A. Koceva-Chyła, A. Guśpiel, L. Oehninger, I. Ott, B. Therrien, J. Solecka and K. Kowalski, Molecules, 2015, 20, 19699-19718.

45 J. Arcau, V. Andermark, E. Aguiló, A. Gandioso, A. Moro, M. Cetina, J. C. Lima, K. Rissanen, I. Ott and L. Rodríguez, Dalton Trans., 2014, 43, 4426-4436.

46 V. Andermark, K. Göke, M. Kokoschka, M. A. Abu el Maaty, C. T. Lum, T. Zou, R. W.-Y. Sun, E. Aguiló, L. Oehninger, L. Rodríguez, H. Bunjes, S. Wölfl, C.-M. Che and I. Ott, J. Inorg. Biochem., 2016, 160, 140-148.

47 J. Schur, A. Lüning, A. Klein, R. W. Köster and I. Ott, Inorganica Chim. Acta, 2019, 495, 118982

48 M.-A. MacDonald, R. J. Puddephatt and G. P. A. Yap, Organometallics, 2000, 19, 2194-2199.

49 A. M. McDonagh, M. G. Humphrey, M. Samoc, B. Luther-Davies, S. Houbrechts, T. Wada, H. Sasabe and A. Persoons, J. Am. Chem. Soc., 1999, 121, 1405-1406.

50 C. Guan, liqing Li, D. Chen, Z. Gao and W. Sun, Thermochim. Acta, 2004, 413, 31-38.

51 K. Alenezi, A. Tovmasyan, I. Batinic-Haberle and L. T. Benov, Photodiagnosis Photodyn. Ther., 2017, 17, 154-159.

52 J. R. Darwent, P. Douglas, A. Harriman, G. Porter and M.-C. Richoux, Coord. Chem. Rev., 1982, 44, 83-126.

53 J.-F. Longevial, A. Yamaji, D. Aggad, G. Kim, W. X. Chia, T. Nishimura, Y. Miyake, S. Clément, J. Oh, M. Daurat, C. Nguyen, D. Kim, M. Gary-Bobo, S. Richeter and H. Shinokubo, Chem. Commun., 2018, 54, 13829-13832.

54 E. G. Azenha, A. C. Serra, M. Pineiro, M. M. Pereira, J. Seixas de Melo, L. G. Arnaut, S. J. Formosinho and A. M. d'A. Rocha Gonsalves, Chem. Phys., 2002, 280, 177-190.

55 J.-F. Longevial, A. Langlois, A. Buisson, C. H. Devillers, S. Clément, A. van der Lee, P. D. Harvey and S. Richeter, Organometallics, 2016, 35, 663-672.

56 J.-F. Longevial, S. Clément, J. A. Wytko, R. Ruppert, J. Weiss and S. Richeter, Chem. - Eur. J., 2018, 24, 15442-15460.

57 A. D. Jenkins, P. Kratochvíl, R. F. T. Stepto and U. W. Suter, Pure Appl. Chem., 1996, 68, 2287-2311.

58 N. Lalaoui, B. Reuillard, C. Philouze, M. Holzinger, S. Cosnier and A. Le Goff, Organometallics, 2016, 35, 2987-2992. 